\title{
What was Multiculturalism?
}

\section{Vijay Mishra, Murdoch University}

Justice is the first virtue of social institutions, as truth is of systems of thought -John Rawls.

Let me begin with an ungainly and selective potted summary of the movement of people over the past two hundred years:

1830-1916: half a million from India to the Caribbean, Fiji, Mauritius 1850-1930: one million Japanese to North America and Brazil 1890-1920: one million per year from southern and eastern Europe to the USA 1920s: three million Spanish, Portuguese, Italians to Brazil and Argentina 1930s: seventy thousand Jews from Nazi Germany to the UK 1955-1962: sixty-seven thousand people a year move from the Caribbean, Africa and India to the UK

1963-1970: One million each year from southern Europe and Turkey to Germany 1975: flow of workers from south and east Asia to the Middle East rises from 100,000 to one million a year

1989-2000: one million to Israel from the former Soviet Union 1990s: an average of 150,000 non-UK citizens move to Britain each year Late 1990s: about 100,000 migrants move to Australia each year mainly from Asia; an average of 350,000 Mexicans to the USA each year; 200,000 Indians and Chinese to the USA each year USA.

Early twentieth century: 250,000 Peruvians migrate to Argentina, Chile and the

These figures, although partial and incomplete, emphasize migration (both of refugees and those seeking better lives elsewhere) as a dominant feature of modernity. The figures also indicate the mix of people on the move and their destinations. Where once these

Portal Journal of Multidisciplinary International Studies Vol. 2, No. 2 July 2005 ISSN: $1449-2490$

http://epress.lib.uts.edu.au/journals/portal/splash/ 
figures were historical facts about migration patterns and necessary for a proper writing of a country's history (the contribution of migrants to nation building for instance), they are now looked at in somewhat different terms, terms that place migrants in a different kind of history. The latter history is one in which it is not simply facts and figures about migration that are discussed, but the definition of the nation-state itself and the migrants' ambiguous sense of attachment to it. In other words, in addition to a type of economic history (objective accounts of demographic shifts in a nation) we now theorize, from precisely these figures, how the nation-state defines itself in ways that lead to a radical rethinking of a nation as a 'multination,' one in which the grand narrative of a nation's founding communities (and the presumption of assimilation upon which the grand narrative was always based) gives way to a multiply-centred narrative attuned to questions of unequal power relations, racism, exploitation and so on. Multiculturalism as a theory has arisen out of this shift and presents itself not as an explanatory model of a given situation but as a problematic in need of continuous theorization.

It is considered chic for a nation to declare itself multicultural: airports say so enthusiastically, politicians declare it interminably, and the media celebrate it. There are essentially two kinds of multicultural nations. There are those old nations that have always been multicultural but which created the idea of a nation-state as a means of transcending difference. Here the nation subsumed cultures as its enlightenment ethos (or so it was argued) allowed principles of liberal humanism to create a just society to which all could belong and for which all could die. So in them cultures were part of the nation, without the nation itself sensing the need to theorize itself in terms of its multiplicity of cultures. In these European old nations, 'multiculturalism' as theory comes as a challenge to an earlier definition of it as empirical fact. The second multicultural nation is one where Gerd Baumann’s ‘multicultural riddle’ has special force (1999). These are settler nations - almost all of the new world (the USA, Canada and also much of Latin America), Australia, New Zealand and, until recently, South Africa. In all these nations territorialization presumed the existence of a non-nation, the land as a tabula rasa, so that there was no Inuit nation, no Maori nation, no Aboriginal nation, no American Indian nation, no Aztec or Mayan nation, and, in the case of apartheid South Africa, no African 
nation, prior to European colonization. In these settler nations, settler ethos became identical with the nation and immigration policies (often a white-only immigration policy that, until the late 1960s, was offered as an article of faith, and proudly too) aimed at creating a monolingual (or as in the case of South Africa and Canada a bilingual) nation under the celebratory sign of (white) assimilation.

In spite of the multiplicity of claims that have been made on behalf of every ethnic community to declare itself part of a multicultural mosaic (because it is fashionable to do so) the multicultural agenda itself is not of the making of ethnic minorities but of the dominant (white) community for whom the management of what the Canadians have referred to as 'visible minorities' is the principal issue. In many ways the excessive zeal with which non-visible minorities have claimed to occupy this space as well, has meant that multiculturalism has often lost much of its political and social (as well as critical) edge, for if every group within a nation is itself a migrant community (except of course the nation's First Nation people), then every nation is by definition multicultural. This argument is quite frankly nonsense because it overlooks a fundamental feature of nations and their link to power. A nation's dominant community (whether as an exclusive group such as the bhumiputras of Malaysia or those who have declared themselves to be part of the nation's grand narrative through ease of assimilation) is never part of the multicultural mosaic; everyone else is. To repeat: a multicultural nation or a multicultural polity is meaningless if each community within a nation-state can equally claim to be part of the nation's multicultural communities. In other words, in any multicultural nation there will always be a cultural imbalance between those (one or two communities) whose history is foundational to the nation and those who have come, as equal citizens no doubt, but whose presence can only have the same legitimacy (in terms of national ideology) retrospectively and even then only after their discrepant narratives have been incorporated into the 'foundational narrative' or when the necessity for the latter has been dispensed with altogether. There is then a presumption of recognition of the other over time as participants in the historical narrative of the land. Failure to recognize this fundamental fact often leads to an idealist or romantic theory of multiculturalism that is often way off the mark. A critical multicultural theory should be wary of this. 
It is important, for my argument, to locate multiculturalism as a problematic essentially around the visible, for without that cultural visibility (colour, religion, dress, food) multicultural theory may be replaced by a theory of 'critical assimilation.' The nexus between the 'visible' and multiculturalism is readily evident in 'ethnic' TV programming in Aotearoa/New Zealand. In a recent essay on television and multiculturalism in Aotearoa/New Zealand, the authors Shuchi Kothari, Sarina Pearson and Nabeel Zuberi (2003) use two programs, Tagata Pasifika and Asia Down Under, as their proof texts to read national readings of multiculturalism. The choice of these programs by the authors locates the central issues of New Zealand multiculturalism in two domains: the Pacific Islands and Asia. In doing so the authors go outside of the country's de jure biculturalism - a biculturalism built on a Pakeha (white) accommodation of the Maori (and vice versa) - to work through a more capacious principle that would make the key partners of New Zealand biculturalism confront the changing face of the country. In this changing face Pacific Islanders - whose homelands survive as remittance cultures - and Asians must have a role to play. So the writers suggest that the uncompleted project of biculturalism should not mean that multiculturalism cannot be part of the full national agenda until that other issue (the Maori-Pakeha question) is resolved. The matter raises interesting questions: first, how can the two targeted groups (Asian 5\% of the population, Pacific Islander 6\%) become part of the larger discussions about land rights, and indeed of the Waitangi Tribunal and therefore an integral part of debates on New Zealand biculturalism? Is this a simple matter of a coalition of Island peoples and Maori, a coalition based on 'common' origin, for minority rights? Where do we locate the Asian in this? Are the interests of the Asians identical with those of the Pacific Islanders? Is it not the case that Pacific Islanders are more likely to be sympathetic towards Maori claims (the indigenous Fijians certainly given their own problems with a migrant community back home) than Asians? What is this category 'Asian'? Is the Fiji Indian an Asian or a Pacific Islander or something yet again? ${ }^{1}$ Is it not true that when it comes to

\footnotetext{
${ }^{1}$ After a lecture at the University of Canterbury on 13 October 2003, an Indian PhD student asked me why Fiji Indians (or Indo-Fijians) and Indians were so different. 'Why the antagonism when this is a neutral space for them?' she asked. But is New Zealand a neutral place for Pacific Islanders (including Fiji Indians) when there has been such a long history of New Zealand engagement with the Pacific? So many Fiji Indians were taught by New Zealand teachers, sat through New Zealand University examinations, studied there, worked there that for them the idea of the country as a 'neutral space' does not even arise. For them
} 
understanding the flows of capital, the acquisition of wealth and an understanding of the Protestant work ethic Asians are in fact almost white, though not quite? Failure to address these questions leads programmes like the Tagata Pasifika and Asia Down Under becoming on the one hand occasions for momentary self-identity (spectators viewing selves as actors) and on the other anthropological diversion for the dominant group. It has been said that Asia Down Under is attractive to mainstream (white) New Zealanders because of its weekly food component. ${ }^{2}$ What the attraction reinforces is food, 'one of the seemingly benign representational systems' of multicultural difference as the positive face of multiculturalism (Gunew 1999, 147). ${ }^{3}$

\section{Theories of Multiculturalism}

Multiculturalism for whom? Who lays down the ground rules? Who are its beneficiaries?

In the end do hegemonic systems (like the nation) always neutralize dissent by incorporating it within a relatively innocuous system? Here are some questions posed in a standard Multicultural Reader. Is multiculturalism antiracist or oblivious to racism? Is multiculturalism cultural autonomy or common culture revisited? Is multiculturalism grounded in grassroots alliances or diversity management? Does multiculturalism link politics and culture or separate them? Who consumes multiculturalism, the salad that it is? Is multiculturalism no more than a managerial strategy to get greater productivity from the work force? In the well-known debate in the pages of Critical Inquiry between Stanley Fish (1997) and Donald Pease (1997), the latter declared: ‘Multiculturalism

New Zealand is what Fiji has ceased to be, an enlightened democracy where the Indian work ethic has value and where, ironically enough, the lost peace of the Pax Brittanica may be reprised.

${ }^{2}$ In an episode of At Home with the Braithwaites (2003), the musical excesses of Bollywood cinema (via Andrew Lloyd Webber and A. R. Rahman's West End musical Bombay Dreams) frames a wedding ceremony where, I suspect, chicken tikka masala is served.

${ }^{3}$ In Sneja Gunew’s argument (1999) something rather more interesting is at work here. Food displaces 'word' (which implies knowledge and dialogue) so that to eat the Other's food (which also generates a series that leads to ingestion followed by abjection) implies that one need not engage with the Other in any dialogic sense. Which is why local multicultural food fairs are so popular with the general public; they are a safe way of acknowledging multicultural difference without the need to engage with those differences. As Gunew points out, early migrants were always registered in dominant consciousnesses in terms of their alien (and disgusting) food habits. The undisguised disgust towards the Indian curry in Britain to begin with and then its celebration as a quintessentially British dish (Chicken Tikka Masala is as British as Yorkshire Pudding) demonstrates the power of cuisine as well as the symbolic incorporation of the alien through food. The point is that food signifies a particular history of accommodation and abjection for, as Gunew says, 'The insistence on invoking food whenever multiculturalism is represented in a positive way is not quite so benign as it may at first appear’ (151). 
(whether the boutique-form of appreciation or the strong form of tolerating) does not exist. It cannot exist because the laws regulating the norms internal to a specific culture necessarily result in incommensurable rationalities' (398). So how does one argue between rationalities that are equally legitimate but incommensurable? Is multiculturalism indeed, as Angela Davis observes, a mode of 'diversity management,' a means of 'preserving and fortifying power relations based on class, gender, and race?' (1996, 41). For the fact is that multicultural programs are not simply enlightened cultural credos, they are means of control that operate across the board from entrepreneurial organizations to the prison correctional system, where it is a means of reestablishing 'control over inmate populations' (42). In Angela Davis' argument one needs to be wary of the 'corporate compartmentalization of multiculturalism' and address how any cultural theory challenges those gender, class and race hierarchies that are at the heart of the American nation-state. In the guise of a democratic utopianism, multiculturalism may even be complicit in a process that obliterates the corporeality of the Other. In this task a critical multicultural theory should always gloss, even as it locates itself as a progressive idea, the historical mechanisms of 'control' that pre-date multiculturalism. ${ }^{4}$

A discourse, as Cynthia Willett observes, which 'demands a coalition of authors, and is especially suited to the genre of anthology' $(1998,1)$ cannot offer a definitive answer, nor can it close off the argument. Nevertheless it is clear that multiculturalism is very much a discourse of the white liberal nation-state to which in the second half of the twentieth century many more post-colonial peoples began to arrive. Whereas an earlier 'multiracialism' remained defiantly colonial in its conception of race (natives, slaves and coolies were its categories of analysis) and had no capacity for self-critique (and hence

\footnotetext{
${ }^{4}$ This consciousness is crucial before we can appreciate Toni Morrison’s observation that on the Pequod (in Melville's great tale Moby Dick) a mainly 'multicultural ... proletariat is at work to produce a commodity' $(1996,27)$. The necessity of an historical consciousness is particularly true of our age, the age of the informational network society about which Manuel Castells has written so persuasively. According to Castells, informational society has created a bipolar world of 'abstract universal instrumentalism' and 'historically rooted, particularistic identities,' in other words an opposition designated by the 'net' and 'the self' (3). How the information technology revolution finally plays out questions posed by multiculturalism or how indeed we can speak about a multicultural society where identities are governed by the Net and not by the Self, are matters that would require research well beyond my ability to do so. I allude to it because of the presumption, perhaps unduly optimistic, that the Net will finally bring to an end questions about individual and collective identities, about class and gender, issues that underpin multicultural theory.
} 
never used the term 'multiculturalism'), the later form (as 'multiculturalism') growing as it did from a post-colonial ethos of multiply-centred cultures and histories began to challenge the glue that had hitherto bound the liberal nation-state together. ${ }^{5}$ But in doing so it never altered real power or class relations, never radically altered the definition of justice itself and saw the nation-state as a 'context' (as Trudeau himself had observed) in which other cultures located themselves and not as a space that may be radically transformed. It remained a structure of control that kept minorities where they are in the guise of a 'colonialist' (white) respect of cultural difference without changing the unified selves of the 'managers' themselves. In the end, multiculturalism remains a thing of the past, a way in which the project of the Enlightenment and matters of justice may be rethought (but not radically altered) so as to accommodate the ‘alien’ within. And it is for this reason - because of its pastness - that it requires constant critique and re-evaluation, the need to specify the real, material conditions of racism and their relation to capital at every point. Like much else in the liberal agenda, the agenda of multiculturalism too may be readily located within unthreatening humanist parameters: individual versus collective rights, the presumption of cultural value (we recognize complex communities that have offered something to world civilization generally), accommodation of minority rights and those of First nation peoples within a dual definition of multiculturalism, the need for benign, liberal, non-racist, non-exclusive policies, the limits to tolerance and the legacy of the colonial order. To give these a further critical turn and to be able to make a case for the 'pastness' of multicultural theory we need to critically examine the received discourses of multiculturalism. I want to consider these under nine headings:

\footnotetext{
${ }^{5}$ Following on from Homi Bhabha's distinction between multiculturalism as a 'portmanteau term for anything' and the multicultural as a 'floating signifier' (1998), Barnor Hesse thinks through a multiculturalism that 'had become a contested frame of reference for thinking about the quotidian cohesion of western civil societies uncertain about their national and ethnic futures' $(2000,1)$. Aware of the differences between American and British readings of cultural diversity/pluralism, Hesse hones in on the differences between multiculturalism and the multicultural (as suggested by Bhabha). For Hesse 'multiculturalism refers to particular discourses or social forms which incorporate marked cultural differences and diverse ethnicities ... [it] can be named, valued, celebrated and repudiated from various political perspectives' (2). Multicultural, a 'colonial formation,' is, on the other hand, a 'signifier of the unsettled meanings of cultural differences in relation to multiculturalism as the signified of attempts to fix their meaning in national imaginaries' (2). Simply put, whereas multiculturalism, the signified, is a discourse or governmental policy that may be discussed in terms of an increasingly diversified nation-state, multicultural, the signifier, refers to those religious, social, linguistic and racial bodies that are grouped 'differently' in everyday social practice. In western nation-states what is really at stake is the nation's prior construction of itself as a unified, homogeneous imagined community.
} 
(1)The Politics of Recognition.

(2) The morally required versus the morally permissible.

(3) Absolute Tolerance.

(4) The Politics of Compromise.

(5) The Inclusive Community.

(6) The Spectres of Class.

(7) The Figure of Woman.

(8) The Post-colonial Condition.

(9) The Radical Imaginary.

\section{(1) The Politics of Recognition}

At the heart of the politics of multiculturalism is the demand for recognition. No theoretician has made the connection as elegantly or as powerfully as Charles Taylor and any meditation on the pastness of multiculturalism must begin with Taylor's influential essay first published in 1992, and slightly expanded in 1994. Taylor uses the words 'politics' advisedly to imply the proactive and indeed interventionist nature of the multicultural point of view. The demand for recognition, of course, is crucial because of the fear of its opposite, of misrecognition or non-recognition, the latter enforcing a caricatured, a distorted, a false mirror of an Other in need of adequate, legitimate, culturally complex and full representation. To not recognize or to misrecognize demeans the Other, condemns her to an image (as it is mirrored in the dominant community) which is negatively stereotypical and lacking in all those characteristics (cultural complexity, philosophical and aesthetic sophistication) by which the Other has defined its being in itself, its own self-consciousness. But the ascendancy of recognition is a recent social event, it came with Hegel's master-slave dialectic which bequeathed a terminology of recognition that, later, fused with democratic ideals so as to make recognition a matter of individual worth and dignity inherent in democracy itself. 'Democracy,' writes Taylor, 'has ushered in a politics of equal recognition' $(1994,27)$. The modern age, synonymous with the democratic age, also ushered in the idea of individual worth, where an individual declares his 'individuality' and right to be different. Here the older notion of adherence to a higher morality (the mark of a person and a characteristic shared by all and hence not 
individuated) is superseded by a new idea of a model to live by that is within us, the ideal of authenticity (31). The insistence on the individual, this monological obsession with the self, is ultimately unreal because the essential element of human life is (as Bakhtin understood so well) its 'dialogical character' (32). The dialogic, then, is crucial for the making of one's identity and it follows that equal recognition when withdrawn or denied, can be a form of oppression since it attacks the very heart of the ideal of 'authenticity.'

The politics of universalism has now produced, in the public sphere, the idea of equal dignity of all citizens (so that there cannot be a second-class citizen) and a modern 'notion of identity,' the latter instrumental in giving rise to a 'politics of difference' (Taylor 1994, 38). The two, however, are not necessarily assimilable or symmetrical as the demand for the latter (identity) in essence wishes to particularize what is, as a principle, universal (dignity), a difference-blind view of people. There is then no room for qualification (say between an evolved, complex culture and an evolving less complex one, the latter proposition itself being contrary to the universal principle of equality and hence racist) which leads Taylor to examine further the politics of dignity. The politics of equal dignity (via Rousseau and Hegel) bequeathed 'a regime of reciprocal recognition among equals' (50). The regime functions in a society with a tight unity of purpose (a common purpose) that conflicts with a regime of differentiation (50). The legacy then of freedom linked to non-differentiation and a common purpose has a homogenizing role which is what is contested in the modern world.

The argument is made clearly by Ronald Dworkin who refers to two kinds of moral commitment: a commitment to ends of life, the good life, which is a 'substantive' commitment; and a commitment to deal 'fairly and equally with each other' which is a 'procedural' commitment $(1996,56)$. Since the idea of a good life is a fact of individual autonomy (after Kant) it follows that a 'liberal society must remain neutral on the good life' (57), from which it follows as well that a liberal society cannot espouse publicly 'notions of the good' (58). Taylor, however, looks at the case of Quebec and that province's reading of the Canadian Charter of Rights (1982) and endorses the manner in which in Quebec legislation (governing the survival of the French language for instance) 
makes 'substantive' part of the 'procedural' commitment of the province whenever questions about the 'integrity of a culture' becomes decisive.

How then does one address procedural liberalism? Does it homogenize difference even if, as in the Quebec example, it patently does not? What are the dangers of the politics of equal respect? Can liberalism offer 'a neutral ground on which people of all cultures can meet and co-exist?' (Taylor 1994, 62). Alluding to the Rushdie affair and mainstream Islam's reading of politics and religion as a unified field, Taylor's argument is that liberalism is not neutral, it is a fighting creed (for its values) but given that societies are now becoming multicultural how can one deal with an essentially diasporic sense of marginalization on the part of many people 'without compromising our basic political principles' (63). And given the legacy of colonization, dispossession and racism that created 'deprecating self-images' of native peoples (Fanon) that the 'our' here carries, how can one ask people to conform without being accused of relapsing into erstwhile, colonialist practices. So liberal democracies are faced with a demand: 'that we all recognize the equal value of different cultures; that we not only let them survive, but acknowledge their worth' (64).

Taylor formulates this as a presumption: 'all human cultures that have animated whole societies over some considerable stretch of time have something important to say to all human beings' $(1994,66)$. Taylor is careful to emphasize that he has deliberately used the word 'presumption' because the claim, to him, has to be demonstrated through a 'fusion of horizons' (after Gadamer) whereby a judgement of another culture would require, through research and analysis, a transformation of our own values or standards. To Taylor the presumption we owe all cultures may be of this kind, which is different from demanding, as a right, this presumption about all cultures. The demand itself is, of course, contrary to the 'difference-blindness' principle of liberal democracies. Furthermore, while we may approach all cultures with the presumption of equal value, it does not follow that our judgement itself would be uncritically uniform; that all cultures are of equal value. Respect, as distinct from condescension requires critical judgment in which there is also implicit a judgment transformed by our understanding of the target culture. If 
we didn’t all cultures, as being uniformly of equal value, are capable of being homogenized and distinctions totally collapsed. The point is made in a footnote (Taylor 1994, fn 41): 'In the end, the presumption of worth imagines a universe in which different cultures complement each other with quite different kinds of contribution. This picture not only is compatible with, but demands judgments of, superiority-in-a-certain-respect.' The overriding choice for Taylor is not between a repressive West and a multicultural utopia; rather it is between culture and barbarism, achoice that requires all cultures (including one's own) to undergo comparative analysis. And for us to accept the worth of cultures generally the presumption has to be re-stated as: 'cultures that have provided the horizon of meaning for large numbers of human beings, of diverse characters and temperaments, over a long period of time - that have, in other words, articulated their sense of the good, the holy, the admirable - are almost certain to have something that deserves our admiration and our respect, even if it is accompanied by much that we have to abhor and reject' (72-73).

Taylor is a liberal Canadian and a prominent philosopher. His argument centres on the question of recognition, some transcendental definition of the subject, the value of cultures and recognition of the special status of the French in Quebec even if the latter may mean the necessity of laws that dictate that except for Anglo-Québécois everyone else should go to French schools. Recognition is the key to Taylor's concept of the multicultural - that in a multicultural polity the foundational fathers of the nation (in the case of Canada its white settlers) are already part of a larger continuous civilization which therefore must have the right to 'recognize' those cultures with a similar continuity. ${ }^{6}$

How does one put the ideal of recognition to practical use? In his challenging book, Theory in an Uneven World R. Radhakrishnan (2003) suggests that one may have to think

\footnotetext{
${ }^{6}$ Both Habermas (1994) and Bhabha (1998), in their commentaries on this essay, see dangers in this presumption: for Bhabha a 'presumption of equality' gets transformed into a 'judgement of worth' (33) which denies the contestatory value of minorities in a nation; for Habermas Taylor's assumption that the 'protection of collective identities' competes with 'the right to equal individual [subjektive] liberties' Kant's original one human right - $(1994,110)$ overlooks the fact that both 'private and public autonomy are equiprimordial' with an 'internal ... conceptually necessary connection between them' (112-113).
} 
through a radical alterity in the form of the subaltern, precisely the figure whose self is excluded from Charles Taylor's politics of recognition simply because he, the subaltern, has nothing of value to offer. His demands are therefore those of the filibustering truculent who has no exchange value since his contribution to anything culturally worthwhile is zero. But it is precisely at the point of the subaltern gaze that recognition needs to play itself out. In phenomenological parlance the subaltern is the limit situation, Kant's native excluded from the category of the sublime, the Tierra del Fuegan or the Aboriginal, from which a politics of mutual recognition may take shape. Taylor had indeed shown the importance of the dialogic in this politics. The subaltern subject position and that of the dominant subject are morphed into a dialogical situation. And again from this new perspective who or what constitutes a legitimate object of knowledge becomes problematic.

However we look at it, though, a politics of recognition implies accepting the persistence of difference. That the latter exists cannot be ignored or deferred through a politics of assimilation. The all-important issue is 'how to receive and practice difference relationally and non-hierarchically' (Taylor 1994, 65). How can one value difference without implying that some differences are to be valued higher than others? Again this is suggestively present in Taylor's essay. If only difference can be located in the inbetween, within a semantics of the hyphen as something that is not located in the identitarian binary of self-other but in what Derrida called différance, the always differing/deferring condition of subjecthood that does not close off identity, is the theoretical challenge to Taylor's principle of recognition. If the mainstream is itself ethnic and has no absolute subject position, if the mainstream declaration of a collective self is built around an illusory unity of the Other (which then confirms its own spurious unity), then it too needs to interrogate its own identity. Of course, it does not (and should not) follow that this recognition of itself would therefore create a level playing field on which distributive justice may be 'liberally' applied. What is the point of a multicultural identity politics when there is universal equality, when 'distributive justice has been achieved?' (Taylor 1994, 67) This utopian moment is of course unreal, and even if realized cannot dissolve difference/différance itself. And at any rate the moment is 
predicated on the idea of a universal reason that has its own roots in the history of liberalism. Multicultural reason, so to speak, would struggle for justice by emphasizing the hyphen, by suggesting that selves may remain 'authentic' while being recognized.

The horizons of different cultural pasts, these other frames of references, are important to bring new multicultural perspectives to acts of consciousness. In this respect

phenomenology confronts cultural difference and redefines consciousness in terms of its placement in different cultures and its investments in them. For the argument is not that everything is therefore culture-specific (the 'one man's meat is another's poison' thesis) but that acts of consciousness must be based on comparisons that recognize the Other as an object of knowledge, that recognize positions of power and presumption, and are able to modify truth conditions accordingly. In other words, the 'episteme of Eurocentrism' and a historicization of western thought 'with reference to the rest of the world' (81) become urgent in any attempt at a proper comparative work. What becomes crucial to a multicultural poetic are a re-definition of 'value' in a multicultural economy, a retreat from the centrist/identitarian binary into a politics of relationality and the location of the Self and Other within rigorously theorized historical realities. (83)

In these dialogues the divide between civilization and barbarism cannot be mapped on to the West and the Rest; the divide inheres within each for both are 'ubiquitous' in culture. But can recognition - even multicultural recognition - attend to matters of distributive justice? Redistribution or Recognition? This is the title of a book in which Nancy Fraser and Axel Honneth (2003) debate the relative merits of these two propositions. How best can we create a society where opportunities are available to all regardless of race, class or creed and at the same time where individual and group differences are recognized? Can the two co-exist? Or is each driven by quite specific objectives so that to collapse both into one would dilute the force of either. For Nancy Fraser the division of the claims for social justice into two - redistributive claims and recognition claims - is a false antithesis because as she says 'justice today requires both redistribution and recognition' (9). What is necessary is a 'two dimensional conception of justice' that can accommodate both claims in spite of the divergent historical origins of the two: the first, redistribution, is a 
liberal, post-Marxist position, the second, recognition, is pure Hegelian. To handle this adequately, one needs to see that both these claims are less philosophical but more 'folk.' They are as Nancy Fraser says, 'folk paradigms of justice' (11). In a sense the failure to merge the two is a result of a critical practice that has seen the two paradigms as advancing different agendas. Whereas the redistribution paradigm focuses on injustices related to economic marginalization, economic restructuring, and working class exploitation and sees these as 'unjust differentials' (15), the recognition paradigm focuses on matters such as cultural domination, the need to radically transform 'societal patterns of representation,' the low status of ethnic groups and either attempts at revaluing devalued social groups or deconstructing the very terms in which such revaluation and celebration occurs. But since neither can nor should subsume the other, it follows that a proper theory of justice, as Nancy Fraser proposes, must involve a “"perspectival dualist” analysis that casts the two categories as co-fundamental and mutually irreducible dimensions of justice' (3).

The respondent to this position, Axel Honneth, does not disagree with Fraser's primary principle - that to understand justice both recognition and distribution should be equally addressed and that recognition is not simply a matter of a superstructure governed by distribution alone. He parts company with Fraser by linking the two but in a dynamic and reciprocal fashion. What Honneth advances is a 'normative monism' paradigm of recognition. In this paradigm rights (economic, class, labour, and so on) inhere in the principle of recognition which has been hitherto defined largely in terms of 'cultural appreciation.' To recognize entails a post-Hegelian, and fundamentally Marxist understanding of cultural value which is a value that is as much about the exchange value of the unit of labour as it is the use value of cultural forms. The case is implicit in his response which is titled 'Redistribution as Recognition' where the argument is one that effectively says that unless redistribution occurs, cultural value, however well defined or recognized as difference, cannot alter social and economic inequality. And Fraser herself recognizes that 'the just distribution of material resources continues to deserve priority on account of its moral urgency' (112). But Fraser is not a normative monist as she reads the two aspects of social justice as parallel aims that must work hand in hand. For Honneth a 
nation-state that distributes unjustly also misrecognizes or in his own words, 'even distributional injustices must be understood as the institutional expression of social disrespect’' (114).

Recognition delineated by Taylor, and refined by Radhakrishnan, Fraser and Honneth, anticipate my concluding argument. And the paper perhaps has not much more to offer. Nevertheless, even as we locate the 'great debates' within the principle of recognition, there are additional theories of multiculturalism, some deferring to Taylor, others parting company radically, that require critical commentary. To these we must now turn our attention.

\section{(2) The Morally Required versus the Morally Permissible: Joseph Carens}

There are of course theories that contest basic liberal principles without sacrificing the ethos of liberalism. The Chicana poet Gloria Anzaldúa collapses Texas/California and the Chicano homeland Aztlán: 'This land was Mexican once,/ was Indian always/ and is./ And will be again’ (1987, 3). The Canadian political theorist Joseph Carens (2000) defends Aboriginal demands for self-government as well as Quebec’s language legislation in ways that are contrary to principles of liberal democracy in that procedural rights become substantial rights. These special demands, seemingly contrary to the ideal of state neutrality on group aspirations, are seen as being contextually neutral and compatible with liberalism because, as Carens argues, actual practice may 'recognize' fundamental principles of democracy (such as freedom of speech, of religion, majority rule) differently. This is not to say that a generic culture of democracy is not a prerequisite for liberal institutions to flourish; rather the cultural specificity of a democratic regime (and let's face it 'every liberal democratic regime is culturally specific') has to be nourished and supported, its virtues constantly disseminated. In his book he pursues this with reference to the very vexed Fijian example. In brief, referring to Fiji, Carens points out that right from the moment when Fijians ceded their islands to Great Britain in 1874, colonial policies ensured that traditional Fijian way of life was preserved, so much so that even Fijian labour was not allowed on European plantations in the colony. The early governors of Fiji took this principle so seriously that they created, at times artificially, 
communal structures of authority (such as the Bose Levu Vakaturaga, 'the Great Council of Chiefs') that would reinforce a traditional life-style against current late nineteenthcentury English preference for liberal individualism. To this end the British brought indentured labourers from India to work on the Colonial Sugar Refining Company controlled (the CSR is an Australian company) sugar-cane plantations. Into a highlycontrolled and structured world was introduced a people who saw individualism as escape from both their erstwhile peasant Indian and current Indenture bondage. What emerged as a consequence were two radically divergent views of liberal democratic principles of two divergent groups: one indigenous, subsistent and collective, the other migrant, entrepreneurial and individualistic. Had native Fijians not been cushioned by interventionist colonial patronage, the introduction of liberal democratic values on them would have been disastrous. Carens, therefore, defends exclusive (and even nonaccountable in legislative terms) policies that were deliberately aimed at preserving Fijian culture: 'the creation of a system of inalienable collective ownership of the land and the institutional reinforcement of deference to chiefly authority through various means' (2000, 202). At this point Carens adds: 'I consider and reject arguments that these measures were inauthentic, unfair, and undemocratic' (202).

The difficulty with Carens's position arises when he has to work through conflicting readings of the nation - one instrumental (of the Indians), the other 'primal' (of the Fijians) - within the first democratic principle of equal citizenship. No matter how careful one is in postulating this first principle as being fundamental to everything else that liberal nation-states stand for, it will come under some form of attack (or at least be valued discrepantly) if one group has privileges so over-riding that their effect is to create a two-tier citizenship. The distinction between the 'morally required' (equal citizenship to Indo-Fijians) and the 'morally permissible' (special rights in favour of Fijian cultural preservation) although a good one with which to begin discussing a delicate Fijian national problematic, nevertheless may be subject to different orders of interpretation. By the latter I mean a shift in reading that would begin to value the 'permissible' above the 
'required,' so as to save a race from extinction. ${ }^{7}$ Western nation-states have been careful not to make laws on 'moral' grounds with respect to either their native populations (where they exist) or oppressed minorities. But the immense value of Carens's chapter on the Fijian example is that it explores a context that problematizes so many of the recurrent themes of multiculturalism that a steadfast adherence to liberal principles (in Charles Taylor subtextually [1994] and in John Rawls formally[1971]) does not address.

\section{(3) Absolute Tolerance: Chandran Kukathas}

What is morally permissible may be reconstituted as a principle of absolute tolerance above what is morally required. Such is the argument of Chandran Kukathas (1997) who takes issue with the subordination of toleration to some other principle (such as equal rights) and effectively asks us to think of tolerance itself as a first, abiding and overarching principle. To do this one has to immediately de-link rights and freedoms from the authority of the state or, put differently, one needs to accept that state authorization is not the only legitimating force behind key democratic ideals such as justice and freedom. Kukathas examines liberal theories of tolerance and finds them wanting. In the case of Rawls (for whom justice is the first virtue of liberal institutions) a just society honours liberty and equality provided that the premises on which they are based can be established by commonly recognized principles of reason (1971). With minor variations here and there, the fundamental fact in liberal theories is that the public sphere itself is a 'reasoning sphere' (in other words the public sphere constitutes the 'Law of Reason'). This being so, rights and privileges can be incorporated into a polity only if they are 'reasonable.' When they are not, a consensus has to be found based upon 'reasoned' debate and without violating the liberal principle of individual autonomy. How could discrepant minority practices be tolerated if they go against the established (and accepted) values of the public sphere? The later Rawls had, of course, admitted that minority opinion should be acknowledged through reasoned consensus for the establishment of a just society (1996, 1999). Kukathas believes that current liberal theory (of Rawls (1996), Kymlicka (2001) and Fitzmaurice (1993), for instance) 'does not give

\footnotetext{
7 The discourse of many First Nation people is one where questions of racial survival are often raised. In New Zealand, attempts to 'water down' Maori privileges (in the name of the morally required) are seen as the first steps in the gradual process by which the race itself may become extinct.
} 
sufficient toleration to minority communities' $(1997,79)$ because the theory assumes that there is a common standpoint which is encapsulated in the idea of public reason. This is largely because it is linked to acknowledged and settled principles. For Kukathas toleration is a principle dependent neither on the state, justice, nor reason; rather it is intrinsic to reason: 'If toleration is forsaken then so is reason' (83). The obvious question that Kukathas directs at himself is: Without a common standpoint, how is any kind of moral engagement possible? The solution is adherence to a range of different moralities, reasons, experiences, all functioning within a 'rules of the commons.' We note the following crucial passage from Kukathas’s essay:

Rather than conceive of the public realm as embodying an established standpoint of morality which reflects a desirable level of stability and social unity, we should think of the public realm as an area of convergence of different moral practices ... what has to be recognized about this public realm is that it is the product of a convergence which produces a stability and social unity that falls short of the permanence or durability many thinkers seek. (84-85)

The social order envisaged here, although lacking values that have been entrenched or institutionalized, is characterized by an underlying toleration. Kukathas would rather have toleration than stability and social unity along the lines outlined by liberal thinkers like Rawls for whom shared values alone give a state its legitimacy.

\section{(3.1) Critique of Absolute Tolerance: Shacher and the Tyranny of Minority Rights}

But absolute tolerance may pose serious problems to minorities within minorities (such as 'visible minority’ women) should Kukathas’s principle lead to the creation of absolute minority rights. This worry provides the crux to Ayelet Shachar's Multicultural Jurisductions (2001). Writes Shacher:

Multicultural accommodation presents a problem, however, when pro-identity group policies aimed at leveling the playing field between minority communities and the wider society unwittingly allow systematic maltreatment of individuals within the accommodated group - an impact which in certain cases is so severe that it can nullify these individuals' citizenship rights. (2)

Shachar calls this state of affairs the 'paradox of multicultural vulnerability,' a paradox for her because rights (based on Kukathas's principle/law of absolute tolerance) given to minorities may be inimical to the more general liberal values of many of the individuals 
who 'inhabit' minority spaces. The phrase and the recognition of vulnerability is not new (many liberals have indeed advanced precisely this argument) but what is new, or rather what is inflected differently, are the juridicial implications of individual rights in the context of minority rights.

Put blandly: if subject A has certain rights because she belongs to a minority that, collectively, has been given these rights, then how could this very subject claim rights in addition to those which, when claimed, contradict the rights (strenuously fought for and achieved) of the group as a whole. Let us say that a devout Muslim minority group in New Zealand is successful in gaining Friday as their Sabbath day and are willing to work on Sundays to compensate for it. And this right is legally vested to them so that each member of the community now has a Friday Sabbath. Subject A is a devout Muslim too, but does not see this as a workable solution as she has children at school with whom she wishes to spend her Sundays (Saturdays are taken up by other household work for her). Can she opt out without creating a chink in the principle itself? Can she continue to work on Fridays and take her Sundays off? Will she be accepted by other Muslims as part of their societal culture? The liberal state will, of course, ensure that the freedom to dissociate is always there but then again we come face to face with individual rights versus collective rights. Are collective rights worth fighting for if individuals within a community can readily dissociate once these rights have been given? If many more take on this option, are we not making a farce of minority rights based on absolute tolerance, enlightened as the idea itself is?

In the end, the argument is one that exposes a significant ideological divide among multiculturalists. On the one hand there are those liberals who argue that liberal democratic institutions have sufficient flexibility to accommodate, on an ad hoc basis, legitimate claims that may come from any group or even from a single individual. On the other hand, there are those liberals who believe that an active legislative culture is crucial to accommodate the needs of a genuine multicultural polity so that minority groups may invoke the power of legislation rather than rely on the whim of juridicial interpretation (the courts) to meet their demands. The latter group of liberals are adherents of a 
differentiated concept of citizenship which is seen as decisively multicultural.

Jurisdictional autonomy is, however, viewed with unease by most multiculturalists of whatever ilk although there are few, if any, examples of such autonomy being granted in the modern Western nation-state. For example, it would be unfair if all Muslims in Britain were to be governed by Islamic marriage practices, antiquated rituals such as female circumcision and hence matters such as divorce, alimony, sexuality and multiple wives were a matter to be handled by an autonomous Muslim body in Britain. ${ }^{8}$ For Shachar 'a conception of differentiated citizenship which is guided by an ambitiously innovative principle' and 'one that strives for the reduction of injustice between groups, together with the enhancement of justice within them' $(2001,4)$ is the answer to the general issue of minority rights rather than a prima facie principle of toleration.

\section{(3.2) Critique of Absolute Tolerance: Michael Walzer and Differential Participation}

For Michael Walzer (1997) the trouble with tolerence as an absolute principle is that groups have participated differentially and at different historical periods in the negotiated settlement of common rules and social practices in any given state. Implicit in this reading is of course the prioritization (after Taylor) of the longest continuous inhabitants in power or those who were the first to usurp power from native peoples: American Puritans, British migrants in Australia and New Zealand, British and French in Canada, and so on. Unless one accepts the negotiated settlement of these early settlers on matters relating to principles of morality and justice, we would end up with a (postmodern) sense of a settlement that was always provisional and immediately open to other regimes of thinking. Although the latter is an historical fact as shift in power has produced different political and legal systems (the historical expansion of Islam is a case in point) this is not a likely scenario in our own age. The point, however, is that there is no historical instantiation of a society at work that considers its own negotiated settlement to be provisional. In Waltzer's argument a 'pluralistic solidarity’ would be far superior to mere tolerance because it has the advantage of leading to a rethinking of reason without

\footnotetext{
${ }^{8}$ See also the Australian April 4 2005, 4: 'A specialist Islamic court is among proposals Muslim leaders have raised with Howard Government ministers to resolve religious disputes such as divorce within Australian Muslim communities.' Under Islamic law, a Sharia court alone resolves disputes about divorce as a nation's civil court ruling is not binding.
} 
foregoing a sense of a unified social order and its principles. Here public reason would grow out of a dialogue among various communities provided that adequate institutional structures and resources are available to all through the state. The recent history of liberal democracies has shown a remarkable acceptance of liberal values by people whose own cultures have values markedly different from those of the liberal West. The fact that democratic institutions continue to flourish in countries like Australia, Canada, the USA and the UK, multicultural polities all, through what Robert Putnam said were networks of civic engagement that fostered 'sturdy norms of generalized reciprocity and encourage[d] the emergence of social trust' (Gutmann 1998, 6) bear ample testimony to this fact. What must be avoided is 'particularized discourse' (Laclau's phrase, 2003) that does not link up with the large trans-ethnic or national concerns about endemic class exploitation and justice in a multicultural polity. ${ }^{9}$ Western democracies are attractive to people not only because of the freedom they give to the individual; they are attractive because of the many material benefits that accrue to citizens therein. And these rights and privileges may be threatened by an uncritical rendition of particularized rights, as a blind extension of what Carens referred to as morally permissible exclusionist rights. In theories of diversity very often the connection between material benefits and support of liberal institutions are overlooked. And tolerance too may not be the self-evident primary concern of minorities who, generally, adapt to the norms established by those responsible for the original negotiated settlement. So what is all the fuss about multiculturalism?

\section{(4) The Politics of Compromise}

In declared multiculturalists such as Bhikhu Parekh the fuss is about accommodation and representation. As part of this agenda we get in Parekh a politics of compromise under the sign of a liberal and humane nation-state (a minimum universalism) which can bend

\footnotetext{
${ }^{9}$ Ernesto Laclau is concerned here with the US version of multiculturalism that aims at recognizing and celebrating difference. The danger is that the celebration then distorts precisely the ongoing struggle for recognition and improvement that takes place within ethnic communities. A further danger is that the celebration of difference also produces demands by groups for narrow advancement policies that are linked to individual groups. Laclau prefers the development of a more comprehensive multicultural discourse, less particularized but one that does not destroy particularity per se. He does not deny the significance of multiculturalism as a means of creating a more participatory democracy; but he is wary of a multiculturalism that could lead to such particularized claims that it fails to address precisely those social forces that threaten to destroy access to justice and equal opportunity. See Olson and Worsham (1999, 129162).
} 
its rules on matters such as separate schools or the teaching of vernacular languages, representations in key public institutions (the police force, the judiciary), fairer readings of the literary canon, incorporation of migrant contributions in the grand narrative of the nation, and so on. Thus Bhikhu Parekh's The Future of Multi-Ethnic Britain ('The Parekh Report' 2000a) and Rethinking Multiculturalism (2000b), endorse universalist or liberal presumptions, which means that in the end forced marriages, female circumcision, rejection of the autonomy of art (within limits), or other practices contrary to majoritarian values of decency or morality or aesthetics are not acceptable. What is elided as a consequence of the universalist presumption underlying Parekh's politics of compromise - and something that has been noted by only a few commentators - are identity politics that work on the basis of, for lack of a better word, postmodern notions of mobility and hybridity. There are in Britain and elsewhere a growing number of people (an entire generation in fact) whose sense of nationality (being British, French, Canadian, Australian or Kiwi) is interpellated through a complex mode of intersubjective engagement and definition of the self. For these people the symbolic struggle over Sikhs and helmets, women and circumcision, backyard killing of animals for halaal meat, the self-evident power of the mullah or priest over congregations in mosque and temple are less important than the ways in which they can become fully-fledged, legitimate subjects in a nation where being British is seen as a racially exclusive category or right. Here fighting mainstream battles about justice and equality at the behest of the underprivileged generally transcends the narrow concerns of ethnic groups. Of course, Parekh’s brief is different since his presumption is that racism is endemic because racists are not given the right kind of information about minorities. In this argument what for Parekh is paramount is the need to redress an educational system that makes little concession to other ethnic values. In the name of a hegemonic liberalism and individual rights, little is done to educate people about non-western values of consensus, reverence of authority and social hierarchy. What is worse, no adequate historical explanations of seemingly pernicious social practices such as caste, first-cousin marriage and polygamy are given. For Parekh, then, only those societies that believe in (and can legislate) a form of minimum universalism can offer 'the most coherent response to moral and cultural diversity' (2000a, 126). For this reason he gives postmodern definitions of subjectivity short shrift. 
Those who believe in contingent and changing selves lack historical depth, and their lives, being ungrounded in culture, are generally shallow and unstable.

Jacob Levy (2000) takes minimum universalism further by stating that the politics of fear and exclusion should be avoided. This is not quite the politics of absolute tolerance in that cultural practices are not so much absolutely tolerated but subtly modified so as to make them acceptable to both the community under fear and the nation's legislators. He refers to the request by Somali immigrants in Seattle for doctors at the Harborview Medical Center to perform female genital cutting. The Medical Centre agreed to a lesser form of genital circumcision, referred to as 'sunna circumcision,' which is a 'small incision on the clitoral hood.' This met the cultural needs of the immigrants and is less harmful than infibulation which is what normally happened to girls as a coming of age ritual. A bitter public dispute ensued which led to the passing of a federal statute criminalizing genital mutilation. Now it is clear from Levy's commentary at this point that the Harborview Medical Center solution responded to a need, albeit in a manner contrary to acceptable public norms, and contained the kinds of public humiliation the Somali ethnic community would have had to suffer (and will suffer) if a culturally enforced female genital mutilation remained the norm for girls aged six in that community. Clearly the principle governing Levy's thesis is self-evidently realist because what is important to him are ways in which real structures are put in place to pre-empt racial abuse and vilification. While the thesis leads to a less fluent and certainly a less engaging mode of theoretical writing, the argument has the merit of informing theory with counter-factual scenarios with which to test many liberal assumptions. Here again absolute tolerance is filtered through a realist principle of least pain to either party (a nation-state that sees certain acts as barbaric and a relic of its own medieval past; a minority group in which members feel incomplete in the absence of the ritual).

\section{(5) The Inclusive Community}

The multicultural state is a political reality. Given this fact, how to work towards an inclusive community is the task of liberal theory. Iris Young (2000), for instance, prefer a 
deliberative rather than an aggregative model of an inclusive democracy. ${ }^{10}$ A deliberative model would be based on a critical reading of preferences and would not simply endorse, as the aggregative model does, 'the most widely held preferences in the population' (2000). When democratic processes simply reflect an aggregation of preferences, there is little room for debate between holders of these preferences; nor is there a consciousness about how preferences, collectively, link up to what the state represents as a morally legitimate polity. Nancy Fraser had referred to them as affirmative and transformative remedies (1998). ${ }^{11}$ Still, as with Stephen Macedo (2000) (for whom diversity is to be acknowledged but not at the expense of sacrificing fundamental liberal democratic values), and David Miller (1999) (for whom social justice is the key to any theorizing of the good since the distribution of good and bad things in life among the members of a human society holds the key to its principles ${ }^{12}$ ), how do citizens become part of an

\footnotetext{
${ }^{10}$ Young's argument is that the decision-making process is the democratic ideal and exclusions from it on the grounds of cultural intolerance, racism, sexism and so on are proof that a democratic society is not living up to its promise (2000, 13-14). In her two models of democracy, the aggregative is a 'pluralist or interest group pluralist' form of democracy since here decisions reflect the 'most widely held preferences of the population.' The trouble with this model is that it is not built upon a critical history of its preferences, nor are the preferences somehow connected to some larger self-justifying or transcendental principle of being, such as justice. When democratic processes simply reflect an aggregation of preferences, there is little room for debate between holders of these preferences, nor is there a consciousness about how preferences, collectively, link up to what the state represents as a morally legitimate polity. Deliberative democracy on the other hand is marked by 'an open discussion and the exchange of views leading to agreed-upon policies' (22).

${ }^{11}$ In terms of Fraser's distinctions, multiculturalism has generally been addressed with reference to affirmative remedies. In other words, remedies have been suggested within the existing socio-economic and juridical frameworks of the liberal nation-state. Against this, transformative remedies (those pursued by queer theorists for instance) question the very basis on which sexual norms get established and are therefore 'deconstructive.' Affirmative remedies have been associated historically with the liberal democratic ethos, transformative with a socialist ethos: the point, as Marx emphatically declared, 'is to change it.' Thus on the question of exploitation of people within a nation-state (poorly paid women of colour for instance) affirmative remedies do not abolish class difference but effectively 'support ... and shape it' (Fraser 1998, 33). The project of mainstream multiculturalism is 'the cultural analogue of the liberal welfare state' (35) since its aim is not to restructure the relations of recognition (as a deconstructive/transformative policy would do) but to superficially re-allocate respect to existing groups and identities. Fraser concludes with the observation that the relations of production in any state must change before real redistribution of wealth can take place. Conversely, cultural practices must be taken out of their presumed and erstwhile norms before group differentiation can be blurred and real recognition given. For the multicultural project, only a nationstate committed to socialist ideals can deliver both. Nancy Fraser's socialist critique of current multicultural practices is nothing new, but it remains very much a minoritarian point of view in the post-Soviet world. ${ }^{12}$ Miller clearly belongs to the school of thinking that finds principles of social justice that would include the whims of almost every conceivable group of people contrary to the overarching values of democracy, individuality and social harmony. In short, a theory of social justice (as distributive justice) has to be based on what he calls 'modes of human relationship' $(1999,25)$. These modes are: solidaristic community, instrumental association and citizenship. Clearly questions about social justice need to address, finally, a growing cultural dominant of Western nation-states: the fact that the contemporary polity is becoming
} 


\section{inclusive community remains paramount especially when the influential American} pragmatic philosopher Richard Rorty (Giroux 1996, 195-99) constructs multiculturalism as a monolithic conspiracy aimed at toppling the consensual basis of American democracy even as he agrees, one presumes with Satya Mohanty that 'human personhood' is a moral notion and individual human worth is non-negotiable as a

progressively multicultural. Not surprisingly even Miller's book ends with a discussion of globalization and multiculturalism. Globalization, of course, poses a rather different and altogether new challenge to social justice. If capital now moves to those countries with the highest return and the lowest forms of social justice (the establishment of sweat shops from China to Fiji are predicated on this correlation), then it is not in the economic interest of a state to emphasize distributive justice (which would include minimum wages, superannuation contribution by the employer, and so on) if it means outflow of capital to other nations. Multiculturalism poses similar threats to the national ethos. Miller uses the term multiculturalism 'specifically to describe the fragmentation of national cultures and the rise of distinct cultural groups whether within or across national borders - whose members' personal identities are linked to their participation in the group' (252). Miller suggests that multiculturalism has three main consequences for social justice. First in the absence of a shared sense of a political community, people may see the distribution of justice either far too narrowly ('what is there for my own ethnic group' argument, for instance) or transnationally (what is there for my global brethren to whom I am inextricably linked through religion, for instance). Second, difference may mean that consensus is no longer something that can be the basis for distributive justice. Although the later Rawls arrived at the conclusion that divergent groups can reach an 'overlapping consensus on principles of justice,' (252) Miller is of the opinion that this is really a forlorn hope. Third, and notably after Iris Young (2000) and Nancy Fraser (1998), the assumption that multiculturalism acts as a corrective to the materialistic base of social justice principles because of its emphasis on the politics of cultural recognition is not an issue of distributive justice. Not surprisingly Miller decisively rejects the argument

that holds that we should respond to the challenges of globalization and multiculturalism by inventing new and more complex forms of justice: if nations are no longer the primary site of justice, then let's have ethnic justice and regional justice and transnational justice all thrown together in one glorious casserole! $(1999,252)$

A minimal starting point, consistency of application, and equality of citizenship are the requirements for justice to operate. In an unusual move, Miller speaks about the need to respond more directly to the challenges posed by multiculturalism. Embedded in the phrase is of course an implicit value judgment: that multiculturalism poses a threat to theories of justice. The case for it has been vastly overstated, he argues, and it needs to be dispassionately examined. In the end Miller does not believe cultural differences (of language, religion, cuisine, and so on) 'inevitably translate into conflicting conceptions of social justice' (261). The tradition from which Miller is writing (the post-Kantian tradition which includes Isaiah Berlin, Rawls and Habermas) is one that sees pluralism as ways of knowing, as a mode of being where all its various (and multifaceted) components are driven by the Enlightenment project of daring to know and where an ethos of commonality, a language of shared values, may be either taken for granted or has to be socially invented. On the matter of social justice at any rate, an enlightened liberal democracy can ensure that it is equally and fairly distributed. The threat to democracy comes when group identities overtake national identities: 'The real challenge of multiculturalism, then, is not that it makes agreement about principles of social justice impossible to achieve, but that it makes it harder for people to see themselves as members of an inclusive community across which these principles are to be implemented' (263). The trouble with this conclusion is that Miller continues to read 'inclusive community' as an abstract polity and not as fully-fledged citizens with degrees of social distinctions at the level of felt-life. As someone like Parekh would retort: to whose definition of the inclusive community should we subscribe, high Tory or those of the Royle family in the popular TV show? 
category of social analysis (1997). ${ }^{13}$ As with many liberal thinkers the fear is that multiculturalism may introduce a variable concept to the absolute, not negotiable, morality of human worth.

\section{(6) The Spectres of Class}

The outstanding absence in multicultural theory is a theory of class largely because multicultural theory has been primarily concerned with identity politics, minority rights and how the liberal nation-state accommodates these. Class, of course, does not belong to the same category as gender, race or ethnicity. It is not, in Edna Bonacich’s words, 'an identity, but a system of economic power and domination. Class relations are not relations of identity, but relations of dominance and resistance' $(1999,298)$. What then is the nature of capitalist intervention in multiculturalism? Is it, as Žižek (1997) and García Canclini (2001) have suggested, the new logic/ideology of global capitalism and really a policy of containment necessary because of the need for labour in western democracies? ${ }^{14}$

\footnotetext{
${ }^{13}$ Richard Rorty wrote in the New York Times that left-wing supporters of multiculturalism were in fact 'unpatriotic' as their position rocked the very foundations upon which national identity and national pride were based. The trouble with Rorty's position, as Giroux demonstrates, is not that it 'equates cultural differences with a threat to national unity' $(1996,197)$ but that it constructs multiculturalism as a monolithic conspiracy aimed at toppling the consensual basis of American democracy. What Rorty overlooks is that national unity is itself a 'shifting, unsettled complex of historical struggles and experiences' (198). Mohanty argues that multiculturalism is a 'form of epistemic cooperation across cultures.' He makes a case for a realist version of multiculturalism (where the presumption of the value of human worth is a not-negotiable transcendental principle) against what are the dominant 'relativist or liberal versions' (1997, 198).

${ }^{14}$ For García Canclini, however, Latin American societies have a distinctly hybrid norm in the figure of the mestizo or mixed race person. García Canclini suggests that Anglo-Americans and Latin Americans have different experiences of globalization because they define the multicultural nature of their nations rather differently: 'What in Latin America has been called cultural pluralism or heterogeneity is conceived as part of the nation, whereas in the U.S. debate, as various authors explain, "multiculturalism means separatism" (Hughes, Taylor, Waltzer)' (2001, 10). In Latin America societies are 'not structured by a multiplicity of ethnocommunitarian groupings' but by practices that go back to 'models of secular republicanism and Jacobin individualism' (11). Of course, arguments in favour of 'a single absolutist patrimony' for the state (as its dominant cultural ethos) and movements 'affirming exclusivistic self-affirmations' have indeed been a feature of Latin American life. But the dominant tendency in Latin America has been towards an affirmation of national identities as being hybrid and located across cultures in an 'asymmetrically interdependent' fashion. It may well be that inherent in Charles Taylor's multiculturalism of recognition is a principle of anticipatory hybridity as recognition of value in the Other may also mean creating identities that would grow out of all these 'recognized' values. For García Canclini what happened in Latin American societies may become a feature of all societies not through an historical imperative (as in the case of Latin America) but through the impact of modes of consumption upon 'forms of citizenship': we are what we consume. The logic of the market may well shape (post)modern identities, making them 'transterritorial and multilinguistic' (29), which, of course implies, that multicultural jurisdictions themselves may well have to be alert to changes that transcend the solidarity principles governing any given nomos. Often the case for minority rights for a group reprises the older definition of identity as belonging to a nation - the same
} 
And in the name of racial and gender diversity do capitalist institutions like universities appoint people other than those who belong to the middle class anyway? To stretch Bonacich's point (1999), the argument really is that multiculturalism is an ideology (a distorted system of beliefs, dare one say even a false consciousness?) that hides the fact that capitalism generates economic and political inequality. Thus it could be said with Elizabeth Povinelli (1998) that the Mabo decision in Australia (that finally put to rest precolonial Australia as a terra nulius) is a control mechanism which keeps the values of the monoculture intact so that claims under Mabo, or even under the Waitangi Tribunal (in New Zealand) must take place under capitalist regimes of thinking. ${ }^{15}$

language, customs, family practices, religion and so on. The shift from a monadic definition of identity (the latter remains an important factor when we address minority rights) to a global multicultural identity (based on consumption) is a matter that has not been subjected to thorough critique. If we were to shift our attention from Western nation-states with large diasporic communities to Latin American nation-states where multitemporal, multiethnic and multicultural heterogeneity is the norm, we may become less anxious about the on-going necessity of state intervention for the creation of a multicultural polity. Of course, in García Canclini's postmodern scenario of consumption based citizenship, there is a postcolonial idealism (the inevitability of hybrid identities) that may not be able to address the here-and-now relations of unequal power and representation.

${ }^{15}$ Liberal investment in multiculturalism takes Povinelli to advance what her essay seeks to understand: 'how the state uses a multicultural imaginary to solve the problems that capital, (post)-colonialism, and human diasporas pose to national identity in the late twentieth century' $(1998,579)$. Povinelli makes an archival reading of the 1992 Australian High Court ruling on the native title rights of indigenous Australians (the Mabo ruling). The Mabo decision has been the single most important symbolic moment in Australian-indigenous race relations since the founding of the (white) Australian nation. The decision was celebrated by the liberal left and grudgingly accepted by the center-right more or less on the same grounds: the decision was accepted only because Australia had recently reconstituted itself (albeit without a Multicultural Act) as a 'multicultural nation.' Yet in this declaration what really happens is that monoculture accepts difference and diversity (under a multicultural template) because the dominant monoculture (as the French/English biculture in Canada) sees this as the proper thing to do by its own Enlightenment rules. In other words, even as multiculturalism is embraced (and land rights to a point endorsed) the transcendental sign of the nation as defined by its enlightened monocultural values remains paramount. This is normative theorizing in a sense, but very powerful because Povinelli is not simply acting out a form of multicultural activism. For Povinelli the (post)narrative of Mabo shows the ways in which multiculturalism becomes the grounds for 'a new form of national monoculturalism' (580). In this new gloss over the old order, the state inflects the registers in which it had hitherto represented itself. Where there was, in the case of Aboriginal land rights, the doctrine of terra nullius (Australia as a tabula rasa upon which territorial rights could be unproblematically superimposed), there are now rights based on common law (from which native peoples had been excluded). Where there was expansionism and the frontier mentality, there is now the language of shame, dispossession, guilt and trauma. Place the two together and the native Other enters the symbolic order of (white) human sciences. Seen in this light the nation-state's juridical and social conscience defuse and divert liberation movements and anti-colonial struggles that native peoples in European settler nations (Aborigines, Maoris, North American Indians) had never participated in. This is as true of the New Zealand Maoris as it is of native Fijians whose own version of land rights must be connected to the absence of a narrative of anti-colonial struggle in their lives. In the case of Fiji, the discourse of anti-colonialism was primarily an Indo-Fijian struggle for independence (modeled on the experience of the Indian motherland). In this struggle the native Fijian lumpen proletariat played no part. And for George Speight and his nationalist followers both the British and the Indo-Fijians 
The cynical reading of multiculturalism is that multiculturalism, as a state ideology, deflects possibilities of a class struggle against a system of economic domination and distorted distribution through an excessive emphasis on ethnic difference. In a timely reminder Bonacich states: 'Somewhere along the line, our concerns over gender and race have led us to lose sight of property relations, or to treat them as an old issue whose time has passed. Marxist ideas are denounced as male and Eurocentric' (1999, 303).

Like Bonacich, Richard P. Appelbaum also declares that ethnicity and gender surface as important elements in global capitalism because 'global capitalism has meant the feminization of labor worldwide, and the ethnicizing of labor on the home front' (1999, 338). It becomes important that the discourse of multicuturalism is read in materialist terms to explore the extent to which 'a highly volatile multiculturalism' is now predicated on exploitation and class 'differences based on race and ethnicity.' In Capital Volume 1 (1967) Marx distinguished between constant capital (investment in machinery whose value is fixed and must be paid off), variable capital (costs as indicated by the wage bill) and surplus value (the unpaid labor extracted by the capitalist which is the source of the capitalist's profit). Since capitalism survives on surplus value, it needs to ensure maximum disparity between variable capital and surplus value. In a period of everincreasing global capitalism, multiculturalism becomes a coded word for the feminization and ethnicization of cheap labour, and hence a source of surplus value: 'From cars to clothing to electronics, the hands that produce our goods and services reveal the exploitative side of multiculturalism: they are hands of color, of women, of impoverished Third World peoples driven by hardship and hunger to labor in the global factory' (Appelbaum 1999, 340). To make this point, Appelbaum points out that in Los Angeles county alone there are around 125,000 garment workers, many of whom are illegal

were equally vulagis ('foreigners'). So a monoculture uses multiculturalism to institutionalise (and neutralise) difference. 'In this liberal imagination,' writes Povinelli:

the state apparatuses, as well as its law, principles of governance, and national attitude, need merely be adjusted to accommodate others; they do not need to experience the fundamental alterity of, in this case, indigenous discourses, desires, and practices or their potentially radical challenge to the nation and its core institutions and values such as 'democracy' and the common law. $(1998,581)$

The subaltern then gets incorporated into a liberal world order of enlightened values even as difference, under the template of multiculturalism, continues to be celebrated. 
immigrants and people of colour. The factory owners are not necessarily white, and racialized exploitation is not necessarily a replay of the old white master/ person-ofcolour slave opposition. No racial group or nation - Koreans and Chinese in Los Angeles or China and Japan - escapes the exploitative logic of racism. ${ }^{16}$ Since capitalism thrives on class distinctions, racism becomes simply a means of rationalizing class.

\section{(7) The Figure of Woman}

Theories of class take us directly to the figure of absolute exploitation already alluded to: the figure of the marginalized, subaltern woman of colour under the patronage of multiculturalism. In a powerful essay Nira Yuval-Davis (1999) has examined the largely under-theorized area of gender relations and multiculturalism. The role of women of colour, especially among minority groups, she argues, is fundamental to any study of multiculturalism. Multiculturalism does not therefore address power relations within ethnic contexts or, at a broader level, discriminatory practices or even policies that affect the lives of many people, and especially women of colour. It follows that a major criticism of multicultural policies is the absence in them of any real theorizing of class positions and 'internal power conflicts and interest differences within the minority collectivity' (Yuval-Davis 1999, 118). When all individuals from a minority community can be rendered authentic, they become equal recipients of benefits that would otherwise go to only those who are most in need of them. In many ways a celebration of cultural pluralism where 'hybrids' challenge (and even erase) the 'totalizing boundaries' of nation-states is marked by an absence of any real engagement with class differences for which as Yuval-Davis suggests a 'transversal politics' is essential. Transversal politics is based on dialogue that takes into account the different positionings of women, or people

\footnotetext{
${ }^{16}$ Of course, as Étienne Balibar’s often reprinted essay ‘Class Racism’ (1999, 322-333) shows, one should not rush headlong into any simple relationship of " "expression” (or, equally, of substitution) between racism and class struggle' (323). The problematic (into which theories of multiculturalism too locate themselves) may be reformulated as follows: nationalism neutralises class conflict by positing a higher mystical unity based on common destiny but transforms the intrinsic narrative of class struggle into a xenophobic exclusion of the Other. In other words, nationalism is intrinsically racist but denotes that the social relation it transcends has a built-in tendency towards racism. This social relation was obviously the class racism upon which 'Aristocratic racism' and its avatar 'colonial racism' (the imperialist always defined himself in aristocratic terms regardless of his own real class origins) were based. Although Balibar does not address multiculturalism as such, it is clear that the kinds of reciprocal determinations he discusses between nationalism and racism, and between class racism and ethnic racism, have invaded discussions about multiculturalism.
} 
in general, but does not grant any of them a priori privileged access to 'truth.' In 'transversal politics,' perceived unity and homogeneity are replaced by dialogues that give recognition to the specific positionings of those who participate in them, as well as the 'unfinished knowledge' that each such situated positioning can offer (121).

In a rather different discourse Susan Okin (1999) also raised these issues with reference to patriarchal endorsement of personal laws affecting women from various cultures: clitoridectomy, forced or child marriage, patriarchal laws governing rape, sexual servitude, purdah and so on (all of which contravene the case for a woman's dignity as being equal to that of a man's). To Okin, claims by minorities that these practices should continue reflect age-old power structures that get transplanted in their new, primarily Western, homes. Their defense by the multicultural body politic (the new enlightened nation-state) cannot be justified as these rights do not adequately represent the rights of the weak within ethnic cultures. For the feminist, multiculturalism and feminism (which challenges all cultural traditions) are mutually exclusive unless multicultural communities undergo the kinds of reform on matters of women's rights that has been a feature of the West for at least a century. There are no group rights that can presuppose unequal gender roles. So for Okin unless a culture is willing to alter itself (and adopt liberal democratic views on women) or failing that become extinct, there can be no moral support for a multicultural policy that defends personal religious laws and practices that are patently anti-feminist. For Yuval-Davis the solution lies not so much in a collective transformation (which can only be an ideal although historically inevitable) but dialogic intervention and self-critique. ${ }^{17}$

\footnotetext{
${ }^{17}$ Gayatri Gopinath in her essay 'Nostalgia, Desire, Diaspora' (2003) makes an important statement about the patriarchal, heterosexual politics of the immigrant Indian communities in the United States. Since these communities position women as 'repositories of an essential "Indianness"... any form of transgression on the part of women may result in their literal and symbolic exclusion from the multiple "homes" that they as immigrant women inhabit' (264-265). The 'non-heterosexual Indian woman' is therefore unimaginable in the 'dominant diasporic and nationalist logics' (265) of the community. Gopinath refers to the case of the Federation of Indian Associations (FIA) sponsored annual India Day Parade in New York. In 1995 the FIA refused members of the South Asian Lesbian and Gay Association (SALGA) to march in the parade. FIA's position on 'Indian queers' and 'Indian lesbians' is not uncommon among multicultural communities generally; Gopinath's essay with reference to the Indian diaspora draws our attention to the gender politics of multicultural communities generally and the general 'unrepresentability of a non-heteronormative (female) subject' in what continues to be a heavily patriarchal and heterosexual understanding of minority rights by minorities themselves.
} 


\section{(8) The Post-colonial Condition}

Britain, a key player in the formation of the modern idea of empire, has been used as the 'cite' to think through recognition and its denial as a legacy of colonialism itself. Barnor Hesse, using the conceptual neologism 'transruption, ${ }^{18}$ in the Introduction to his edited volume Un/settled Multiculturalisms (2000, 5) asks, 'Why is it that in Britain there has been no serious debate about multiculturalism as part of the mainstream political agenda? ${ }^{, 19}$ In other words, as a 'spectre' and as the threatening return of the repressed within, multiculturalism is silenced, debates about it seen as a way of 'splintering' the nation. Hesse then goes on to trace the 'reasons why the politics of multiculturalism [became] a non-debate in Britain by the middle of the 1990s’ (5).

In Britain, of course, multiculturalism is directly linked to the question of post-1945 'nonwhite’ immigration and to the various right wing (expulsionist) and liberal (from assimilationist to cultural 'celebrationist') responses to the question of national integration. Having recognized, with Floya Anthias and Nira Yuval-Davis, that 'ethnic and racial divisions get reproduced from generation to generation $(1992,158)$, the liberal response was to actively valorize the aesthetic domain of cultural difference without addressing the questions of power relations. This very same valorization was then read as a threat to things essentially British by the Right. In the end, as Hesse points out, the fundamental issue of racism in Britain was sidelined. The difficulty with multiculturalism in Britain was with its generalized conception, as if in its generality (equal value of all cultures without, in Charles Taylor's terms, a theory of recognition) it could offer full explanations about discrepant, indeed contradictory, social representations and national

\footnotetext{
18 'Transruption,' says Hesse 'comprises any series of contestatory cultural and theoretical interventions which, in their impact as cultural differences, unsettle social norms and threaten to dismantle hegemonic concepts and practices.' They 'disarticulate the logic of discourses that seek to repress, trivialize or silence difference' (17).

${ }^{19}$ For Hesse 'multiculturalism refers to particular discourses or social forms which incorporate marked cultural differences and diverse ethnicities ... [it] can be named, valued, celebrated and repudiated from various political perspectives' (2000, 2). Multicultural, a 'colonial formation,' is, on the other hand, a 'signifier of the unsettled meanings of cultural differences in relation to multiculturalism as the signified of attempts to fix their meaning in national imaginaries.' Simply put, whereas multiculturalism, the signified, is a discourse or governmental policy that may be discussed in terms of an increasingly diversified nationstate, multicultural, the signifier, refers to those religious, social, linguistic and racial bodies that are grouped 'differently' in everyday social practice. In Western nation-states what is really at stake is the nation's prior construction of itself as a unified, homogeneous imagined community.
} 
identity to all and sundry. What is now urgent, and this is Hesse's primary point, is the necessity to contest British multiculturalism (in its however residual form) 'as symptomatic of an unresolved post-colonial condition following decolonization, the dismantling of the British Empire and post-war migration from the erstwhile colonies' (11). It is then the particular - diasporic formations in Britain, the nation's imperialist legacy - that requires factoring in a theory of multiculturalism. The latter must address the legacy of colonialism at the heart of the British nation and difficulties the British have had in coming to terms with its 'post-colonial' condition. In Britain especially the need for a 'particularized' post-colonial British multiculturalism sensitive to the nation's historical formation is therefore essential. For what has happened is that the particular has been subsumed by the idea of a 'tolerant British nation which is intrinsically uninformed by historically racist processes’ (12). In Britain, then, multicultural theory (and practice) must address the nation's colonial history and its 'incomplete process of colonization' so as to readdress the impact of Black and Asian migration on 'the racially exclusive narcissism of the nation' (15). Multiculturalism needs to be aware of discrepant ways in which diaspora thought affects the nation, the ways in which 'unresolved discrepancies' need to be acknowledged as being crucial to an understanding of the modern nation. What the dominant discourse must acknowledge is the continuing validity of these alternative points of view, alternative life worlds that cannot be repressed. Hesse calls these discrepancies, these eruptions, multicultural 'transruption,' which signifies the constant and 'recurrent exposure' of the discrepant in the nation-state.

In the concluding essay to Hesse's volume Stuart Hall too argues that the new multiethnic and multi-cultural nation-states grew out of the 'dismantling of the old empires' and 'reflect their prior conditions of existence under colonialism' (2000, 212). An understanding of the connection between the two is necessary before one can explain, especially in the context of Britain, the neo-imperial character of race relations in multicultural Britain. At the same time we need to be conscious of three broad shifts: the end of the old European imperial system, the end of the Cold War and the spectre of globalization. At one level these three forces may well suggest a new world order no longer marked by ethnic or class difference, or an agonistic politics since the triumph of 
individualism and capitalism introduces an order marked by wealth and not ethnic, religious and cultural difference. Reality in fact tells a rather different story. For instance, even as globalization signals the idea of the universal subject, it produces the figure of the subaltern who stresses his or her difference. Indeed the 'classic Enlightenment binary between Traditionalism and Modernity is displaced by a disseminated set of "vernacular modernities"' (Hall 2000, 215). In other words, the symbols of modernity are acquired but on their own terms so that global and local interests remain in tension. Hall reads this tendency as an instance of what Derrida referred to as 'différance' and suggests (after Homi Bhabha) that différance is played out best in the 'borderline time' of minorities. What is produced is a localism which is not simply a residue of the past (such as a return to absolute religious beliefs) but ‘something new - globalization’s accompanying shadow; what is left aside in globalization's panoramic sweep, but returns to trouble and disturb globalization's cultural settlements' (Hall 2000, 216). The form this localism takes (progressive, creative, fundamentalist, integrative) depends upon the politics of the host nation in which minorities are located.

As the concluding essay in Hesse's edited volume, Hall's essay looks at the particular case of Britain in terms of Hesse's idea of the 'transruptive force.' The British have seen themselves as a unified culture suddenly threatened with the arrival of Blacks and Asians in their midst. The 'multicultural question' is therefore seen as something that came with the arrival of the SS Empire Windrush in 1948, bringing the first Caribbean migrants, a history so powerfully shown in Andrea Levy's remarkable novel Small Island (2004). Hall's point is that the multicultural question has been part of Britain's domestic and colonial histories and that British attitudes towards coloured immigration simply replicated the older colonial attitude of subordination and exclusion. It is this attitude that has blinded the nation from addressing the new 'racialized, ethno-cultural and religious identities' in the country. Given the nation's prior belief in its own unified culture (a culture into which admission for the colonized outsider was a non-issue) the British (like their settler nation counterparts elsewhere in Australia, Canada, New Zealand, the United States and for a long while South Africa) simply worked on the presumption of final assimilation of subaltern difference. What happened in fact was that these coloured 
diasporic communities offered a ‘novel cultural configuration' (as ‘cosmopolitan communities') contrary to the logic of full assimilation. They were also seen both as a relic of a communal sense that 'liberal society is supposed to have lost' and as 'the most advanced signifiers of the urban postmodern metropolitan experience' (Hall 2000, 221).

The first 'transuptive impact' of these diasporas was on the received definitions of 'race' and ethnicity. As with the idea of a unified British culture so too with race as the British saw themselves as a unified body (to which the term race cannot be applied) against which ethnic difference may be measured. Indirectly then race has reared its head albeit 'under erasure.' Hall argues that of the two major non-white communities in Britain the term 'race' is applied to Afro-Caribbeans and 'ethnicity' to Asians. Although 'race' is not a scientific but a social category, its implied application primarily to Blacks incorporates in its very definition racist characteristics (skin colour, shape of the nose, and so on) that transform a social definition into a genetic or 'natural' one. And although 'ethnicity' (not 'race') is applied to Asians because the latter's cultures and religions are most on display, even here the biological referent that characterizes race is never totally absent. If the category of 'race' had defined Blacks as being indolent and congenitally indisposed towards the work ethic, the category of 'ethnicity' brought genetic characteristics (feminization of the body, incapable of playing sport) to the Asians as well. The multicultural question then becomes twofold: on the one hand it must address questions of racism (because the reading of both Black and Asian is ultimately racist) and at the same time engage with racial difference because even after two generations these multicultural communities have not become part of an unproblematic Britishness.

This leads naturally to the 'transruptive' effect multicultural communities have had on definitions of culture. Post-Enlightenment modernity has offered the opposition of 'Particularism versus Universalism, or Tradition versus Modernity' as the framework within which to examine culture. To combine categories that are in opposition is seen as a relic of the Middle Ages and a logical impossibility in the modern world. So modernity cannot understand the idea of a traditional Islamic modernity or diasporas espousing antimodern sentiments (such as the burning of a book, female genital mutilation or the fatwa) 
while at the same time claiming to be modern. Here Hall, once again borrowing from Bhabha, puts forward the 'transruptive' category of 'hybridity' as the cultural logic of translation, the mark of the place of the incommensurable in diaspora when seen from the post-Enlightenment tradition/modern divide. Writes Hall, 'In diasporic conditions people are often obliged to adopt shifting, multiple or hyphenated positions of identification' (2000, 227). A hyphenated declaration of citizenship is often the norm as Black and British or British-Asian descriptions are not uncommon. What these imply is the presence of the principle of heterogeneity and hybridity in the life of diaspora. 'They are all,' writes Hall, 'negotiating culturally somewhere along the spectrum of différance, in which disjunctures of time, generation, spatialization and dissemination refuse to be neatly aligned' (227).

A third 'transruptive effect' of the new multiculturalism is the challenge the latter poses to what looked like a settled terrain of differences between the liberals and the communitarians. What is at issue primarily is the self-evident universalism of postEnlightenment liberalism. In other words, the latter tradition looks less and less like a universal principle of reason and proper governance and more and more like a particularity (a European historical particularism) that masquerades as a universalism since it is grounded 'in the customs, habits and rituals of everyday life' (Hall 2000, 229). Its tenets of universal citizenship and cultural neutrality no longer hold good in multicultural polities; multicultural difference is now making headway into the domain of the rational and the universal as personal and communal codes transform the neutrality of law and introduce exceptions as not unqualified precedent. Recall the right of Sikhs to wear turbans and the acceptance of 'consensual arranged marriages' (Hall 2000, 231).

These transruptive effects lead Hall to pose the question: 'What are the premises behind a radically distinctive form of British multiculturalism?' (231). The nation will have to reflect on its racism and the ways in which biological racism continues to shadow questions of cultural or ethnic difference; the nation will have to critically rethink its own majoritarian logic and reconfigure itself in a 'radical post-national form' (232); it needs to understand that migrant communities 'bear the imprint of diaspora' (232) since they are 
vertically integrated into their own communities even as they laterally link with other communities. A greater cultural diversity at the heart of modernity without relapsing into ethnic absolutism or closure should be the aim as one rethinks, after Laclau, 'one's relation to [the] past as a critical reception' (233).

If indeed 'western particularism' came to be rewritten as 'global universalism' as hall says (234), can we not see how difference, the particular, can be located in the heart of the universal? Is it a matter of reaffirming democracy or of accepting, as Hall argues, that democracy is always a struggle for justice, for the right balance between competing, and equally defensible, positions? One has to, in short, 'effect a radical reconfiguration of the particular and the universal, of liberty and equality with difference' (236). A deepening of the democratic ethos must work hand in hand with an 'unrelenting contestation of every form of racialized and ethnicized exclusionary closure (whether practiced by others on minority communities, or within communities)' (236). A more inclusive Britishness should be the ultimate goal.

\section{(9) The Radical Imaginary}

Stuart Hall is aware that this new political logic is a lot harder to put into practice than to theorize and it is the former (the practice) that has invariably led to arguments that are in the end circuitous, offering the right critique but unable to transform national consciousness. The need for a transformation is at the heart of Richard J. F. Day's capacious Multiculturalism and the History of Canadian Diversity (2000). The book has an historical sweep - the extent to which Canadian multiculturalism continues the discourse on diversity begun with Herodotus - and theoretical investigation - is 'the current state policy of multiculturalism ... a stage on the way to a 'post-industrial Sittlichkeit?' (3). On both these premises, Day's conclusions verge on the cautious. He sees Canadian multiculturalism not as a solution to the age-old problem of diversity but as an extension and re-thinking of that problem. In other words, Herodotus's diversity scheme, the problematic that it is, continues to fester. And as for the new post-industrial ethical order implied in Canadian multicultural policy as suggested by Charles Taylor, the goal remains elusive as the policy has become a way of managing diverse identities and 
not the establishment of a new order that transcends the relations of power (master and slave) 'found in the "deficient” Hegelian forms of recognition' (3). Lest this position is seen as endorsing the Conservative criticism of multiculturalism as the royal road to the destruction of a fragile Canadian unity, Day argues that he is not against the policy as such. What he critiques is the claim that the policy should create a state of total recognition of difference and reconciliation of disparate claims. The history of diversity has had this underlying ideological thrust - to create a unity out of diversity, initially a Franco-British diversity, and now a multi-ethnic diversity. Day argues that the Canadian citizen must go beyond the 'fantasy of unity,' that unity is the final goal of multiculturalism or indeed of the nation itself. For him multiculturalism as 'radical imaginary' has to be separated from multiculturalism as 'state policy.' The latter leads to 'management, discipline and uniformity,' the former to a creative and 'spontaneous emergence' of a vibrant, though not necessarily reconcilable, nation-state.

The trouble with Canadian multiculturalism is that it continues to see diversity as a problem to be solved and Canadian history is replete with attempts at managing 'ethnocultural identities' (5). Against this the Canadian state claims that diversity has been solved or is a non-issue because the Canadian state has been multicultural from its very inception with claims made that cultural diversity was part of Canada's aboriginal peoples as well as, of course, the two dominant European settler communities: the French and the British. This claim is not uncommon as many other nations, including European nations, have said as much in defence of their own policies managing post-war ethnic diversity. Stuart Hall's essay had made this clear with reference to Britain. Day does not buy this self-aggrandising reading of multiculturalism but pursues critically how recognition may be granted or attained. Drawing upon Hegel, Lacan, Taylor, Kymlicka, Bhabha, Žižek and Derrida, Day argues that 'multiculturaist theory and practice must traverse the fantasy of fullness associated with the modern nation-state' (12). He continues, 'Only by abandoning the dream of unity, Canada may, after all, lead the way towards a future that will be shared by many other nation-states; it may, in its failure to achieve a universal mass identity, or even a universal mass of identities, inadvertently 
come closer to its goal of mutual and equal recognition amongst all who have chanced to find themselves within its borders' (12).

The project should not imply that questions of race, sex and gender should remain private concerns and justice is dispensed with. Towards the end of his book Day returns to the question whether multiculturalism ('as political theory and philosophy') points towards 'an ethical community of equal and mutual recognition - a Sittlichkeit' (177). The difficulties posed by in some sense this utopian ideal cannot be disentangled from the history of the nation itself. In the case of Canada the ongoing will to control and manage, to dissociate language from culture (Trudeau's well-known references to two official languages of Canada but no official culture) continues to present diversity as a problem in need of fixing rather than diversity as an energizing principle that redefines the nation. The multicultural after all begins with the presumption that a homogeneous group (or groups who have created a sense of this homogeneity as in the Franco-British compromise in Canada) must find ways of controlling a growing diversity. It does not begin with diverse ethnocultural groups finding ways in which they may respond to the presumed homogeneous group. Day does not articulate it in quite this fashion but his references to the counter epistemology of the hybrid and his general unease about the primacy given to the Hegelian model of recognition suggests some such unease.

Working through Kymlicka's theory of a non-procedural liberalism which would allow for a theory of minority rights to exist alongside traditional human rights and individual freedom and Taylor's well-known thesis about recognition granted to cultures of value and historical depth, Day concludes with notes towards a multicultural 'radical imaginary.' First, multiculturalism as theory and philosophy should go outside the fold, outside the domain of a state-sponsored 'rational-bureaucratic action' to solve the problem of diversity $(2000,222)$. The state must cease to see itself as the neutral ground in which dialogue between diverse ethnic groups can take place. It should also deconstruct its own locale in a colonialist, in this case, Canadian, history. The point that Day makes, and forcefully too, is that the state has its own ideological roots, its own bias, its own stake in ensuring that its version of culture and society remains the norm. 
Although the liberal argument is that the personal is not the business of the state, the fact remains that the state has always been based on some values of some 'persons.' Day formulates this as a question: 'If the current forms of social and political organization are 'not necessarily' connected to any particular culture or ethnicity, then why is there such resistance to putting them at risk?' (223).

Day refers to the 'fantasmatic structure of Canadian multiculturalism' because it is predicated on the prior condition of a Canadian culture and this culture can be readily recovered or accessed. The fullness and harmony associated with these reveries is no more than a myth not because this harmony is glaringly spurious but because this harmony represses those exclusionary principles necessary to hold the myth together. Day’s history of Canadian diversity acknowledges the repressed, the dark side of Canadian history. To do so Canadian multiculturalism must, as he puts it, '(i) openly admit and orient to the impossibility of full identity; (ii) affirm the value of difference and the Other as such; and (iii) recognize the necessity of a negotiation of all universal horizons, including that of the nation(s)-state' (224). The state must therefore acknowledge that there is no correct 'person-type' to which the polity should aspire since the type has never existed. The state must acknowledge difference and not strategically incorporate difference into its own system of quasi-assimilation. What the Other does is that it 'demands' that the Self modifies its own structures, to acknowledge that both the Self and the Other are situated 'in an impossible quest for identity amidst the endless play of difference' (225). It follows that no identity can be prioritized over another and if it has been we must confront the reason: colonial institutions that replicate only its own hegemonic form of subjecthood. For Day then, the role of the Canadian state should be to provide a space for a degree of free play, without necessarily endorsing any particular ideology. In this space of free play anything could be on the ascendant but the ascendancy may be only momentary as it would be subject to revision. What is preferred is not a 'static, solidified order, but a dynamic and fluid chaos' (225). To dissolve the problem of Canadian diversity, says Day, the project of multiculturalism as advancing Canadian unity must end. The Québécois nationalist position and the Canadian First Nation position on this are absolutely identical: both recognize that they are seen by 
English Canada as 'competitive aberrations to be eliminated, absorbed, or merely recognized' (227). And isn't this the agenda of (Canadian) multiculturalism? Concludes Day:

In affirming difference as such, recognizing the impossibility of identity, and accepting the necessity of an ongoing negotiation of all universal horizons, Canada could start to move from multiculturalism as deep diversity - as 'more well-managed difference' within an authoritarian and hierarchical capitalist state form - to multiculturalism as radical imaginary, as différance, deterriorialization, more-than-life. (227)

\section{Conclusion: The Universal and the Particular}

In general terms the issues raised above congeals around the question of subjectivity, especially in the wake of the structuralist declaration of the 'death of the subject.' The ramifications of this declaration (which governed the field of literary and cultural theory for some time in the 70s and 80s) were felt across disciplines and led to an insistence on multiple identities against the idea of a singular, transcendental one. I want to use Ernesto Laclau’s brilliant essay ‘Universalism, Particularism and the Question of Identity’ (2003) to make a case for a realist understanding of the 'pastness' of multiculturalism. The essay does not see diversity as a problem; rather it makes a case, with which I am in agreement, that the post-Marxist principles of universalism (class, gender, and so on) have to be internalized within the particular not because of any hegemonic stipulation but because the principles of universalism were themselves 'particular' (linked to a specific western historical formation) and this particularity (now rendered as a universal) is a particularity that may be located within all particularisms. If the place/terrain from which the universal subject spoke is non-existent, then a space is created for the evolution of multiple identities, and new forms of multicultural subjectivities. The divide now is not between a subject position and the absolute signified of transcendentalism, but between the particularism of the multicultural Other versus the implied universalism of the Self. Or, presented as a question, can particularism now dictate an economy of differences in terms of other 'particularisms?' In the latter, identity simply becomes particular outside of the universal.

The relative merits of the particular and the universal have been traditionally located within two propositions: first there is an absolute divide between the two, in that one 
cannot be both, and second the universal must have priority over the particular because the universal alone can be rationally defended. The universal is therefore a principle that inheres post-Enlightenment modes of thinking, the particular is its aberrant and even recalcitrant other. But this universal, in post-Enlightenment Europe, was nothing more than a European particularism which presented itself as the universal. Nowhere is this more evident than in the history of imperialism, which may be seen as the ‘universalization’ of a European 'particularism' (Laclau 2003, 362). Here of course particularism was hoisted on to colonized peoples, peoples without history, who were in need of the civilizing mission of Europe. Laclau's narrative moves to its inevitable conclusion: 'the universal is no more than a particular that at some moment has become dominant and there is no way of reaching a reconciled society’ (363).

But the 'proliferation of particularisims' as we have seen in recent times (and which certainly shadows multicultural thinking) does not offer an easy solution to current problems about difference. At its most awkward, defence of particularisms (which may inform the principle of absolute tolerance) produces the following logic:

I can defend the right of sexual, racial and national minorities in the name of particularism; but if particularism is the only valid principle, I have to also accept the rights to self-determination of all kinds of reactionary groups involved in antisocial practices. Even more: as the demands of various groups will necessarily clash with each other, we have to appeal - short of postulating some kind of pre-established harmony - to some more general principles in order to regulate such clashes. In actual fact, there is no particularism which does not make appeal to such principles in the construction of its own identity. (Laclau 2003, 363)

Pure particularism thus produces the ideal of harmonious co-existence within a coherent whole. But this ideal overlooks power relations within the groups that make up the coherent whole. It also overlooks the principle of separate developments along the lines of apartheid because each and every particular is its own self-contained universe. Realistically though the identity of an ethnic minority, for instance, can be fully achieved only if it is recognized as such by the nation-state. Laclau uses the word 'integration' instead of 'recognition' because he wishes to make it clear that along with the realization of an ethnic identity there is also an implicit demand that the achieved identity will share equally in the universal principles of social justice and fair play available to all citizens within the nation. This leads Laclau to put forward a further definition of the universal 
and the particular: 'the universal is the symbol of a missing fullness and the particular exists only in the contradictory movement of asserting at the same time a differential identity and canceling it through its subsumption in the non-differential medium' (364).

For Laclau, then, self-enclosed identities that make no reference to what is outside are neither 'viable' nor 'progressive.' It makes no sense for minorities in Europe for instance to refuse to participate in European institutions because to maintain pure identities plays to the logic of apartheid and forever creates the binary of the oppressor and the oppressed. 'A particularism really committed to change,' must therefore reject 'both what denies its own identity and that identity itself' (365). So identity requires constant negotiation so as to critique the dominant group (which denies minority identity) as well as self-reflect on its own demands for particularism. The shaping and re-shaping of identities within a dialectical and not oppositional politics is at the heart of multicultural thinking too. For Laclau there are a number of divergent courses that multiculturalism can follow. One is to 'affirm, purely and simply, the right of the various cultural and ethnic groups to assert their differences and their separate development' (366). This is, in other words, no more than the opposition of one particularism with another and is ultimately segregationist. The proper proactive solution is for particularism/difference to be asserted within a 'global community' in an a priori principle that is dictated by coexistence. Laclau asks a question that holds the key to multicultural thinking: 'Now, how could that coexistence be possible without some shared universal values, without a sense of belonging to a community larger than each of the particular groups in question?' (366).

The role of negotiation remarked above is, however, fraught with difficulties since the outcomes of negotiation are ultimately a matter of a balance of power within competing communities and are never something undertaken on a level playing field. There may be alliances based on mutual give and take but neither a sense of 'collective will' nor of community can arise out of such a fundamentally undertheorized notion of negotiation. What needs to be undertaken is based on a proper understanding of universalism itself. For, 'it is one thing to say that universalistic values of the West are the preserve of its traditional dominant groups; it is very different to assert that the historical link between 
the two is a contingent and unacceptable fact which can be modified through political and social struggles’ (366). This was indeed the argument of Mary Wollstonecraft who said that it made no sense to have universalistic human rights that ignored women as a group and simply advanced the rights of one section of the community. The historicizing of universalism would show that it was an ideology that began with the presumption that a nation was homogeneous, that Europe was the centre of the world and that it was selfevidently rational. The world as it is cannot be understood in terms of this understanding of universalism. The unresolved tension between universalism and particularism now brings us closer to a different, a lot more energetic democracy that would take us away from Western Eurocentrism through an operation that could be called 'a systematic decentring of the West' (Laclau 2003, 367). 'Eurocentrism [itself],' writes Laclau, 'was the result of a discourse which did not differentiate between the universal values that the West was advocating and the concrete social agents that were incarnating them’ (367). Laclau then proceeds to separate these 'two aspects.' If minority struggles show that actual practice restricts the 'universalism of our political ideals to limited sectors of the population' (here the majority population), then its spheres of application must be widened even as its 'universal dimension' is retained. The ‘concrete contents' of this new universality can then be defended more fully: 'Through this process, universalism as a horizon is expanded at the same time as its necessary attachment to a particular content is broken.' To reject universalism outright on the grounds that it belongs to a single group doesn’t do anyone any good. If we can see the universal not in terms of a definable content but as a 'receding horizon' that is flexible enough to accommodate demands other than those enshrined in its putative content, then we can enter creatively into the heart of the paradox: which is that universality is incommensurable with particularity but 'cannot exist apart from the particular’ (367). The paradox cannot be resolved, nor should it be resolved for the tension between the two, their non-resolution, creates the vibrant social conditions within which a democracy can thrive. The solution, if there were one, would imply that the true content of the universal has been found once and for all and there is no need for a 'radical imaginary.' This would then be contrary to democracy as a social politics in which there must always be a struggle between competing groups for a certain particularity to become universal. In a very real sense multicultural theory makes us 
recognize a process of competition as well as the impossibility of arriving at a society secure in its universality. Laclau's brilliant essay spells out a dichotomy in (multi)culture that need not be resolved but an understanding of which is crucial to a healthy democratic polity. For, after all, multicultural theory can only exist within the confines of such a democracy.

\section{Reference List}

Alcoff, L. M. \& Mendieta, E. (eds) 2003, Identities: Race, Class, Gender, and Nationality, Blackwell Publishing, Oxford.

Alperson, P. (ed). 2002, Diversity and Community: An Interdisciplinary Reader, Blackwell Publishing, Oxford.

Anthias, F. \& Yuval-Davis, N. 1992, Racialized Boundaries, Routledge, London.

Anzaldúa, G. 1987, Borderlands/La Frontera: The New Mestiza, Spinsters/Aunt Lute, San Francisco.

Appelbaum, R. P. 1999, 'Multiculturalism and Flexibility: Some new Directions in

Global Capitalism,' in Race, Identity, and Citizenship: A Reader, eds R. D. Torres,

L. F. Mirón and J. X. Inda, Blackwell Publishing, Oxford, 337- 354.

Arteaga, A. 1997, Chicano Poetics: Heterotext and Hybridities, Cambridge University Press, Cambridge.

Balibar, E. 1999, 'Class Racism,' in Race, Identity, and Citizenship: A Reader, eds R. D.

Torres, L. F. Mirón and J. X. Inda, Blackwell, Oxford, 322-333. 2002, Politics and the Other Scene, Verso, London.

Barnor, H. (ed). 2000, Un/settled Multiculturalisms, Zed Books, London.

Baumann, G. 1999, The Multicultural Riddle. Rethinking National, Ethnic and Religious Identities, Routledge, New York and London.

Bhabha, H. K. 1998, 'Cultures in Between,' in Multicultural States: Rethinking

Difference and Identity, ed D. Bennett, Routledge, London and New York, 29-36.

Bissoondath, N. 1993, 'Escaping the Cultural Imperative,' [ Interview], Rungh, vol. 1, no. 4, 8-13.

1994, Selling Illusions: The Cult of Multiculturalism in Canada, Penguin Books, Toronto.

Bonacich, E. 1999, 'The Site of Class,' in Race, Identity, and Citizenship: A Reader, eds

R. D. Torres, L. F. Mirón and J. X. Inda, Blackwell, Oxford, 297-303.

Braziel, J. E. \& Mannur, A. (eds). 2003, Theorizing Diaspora: A Reader, Blackwell

Publishing, Oxford.

Brennan, J. (ed). 2002, Mixed Race Literature, Stanford University Press, Stanford.

Brown, R. H. (ed). 2003, The Politics of Selfhood: Bodies and Identities in Global

Capitalism, University of Minnesota Press, Minneapolis.

Carens, J. H. 2000, Culture, Citizenship, and Community: A Contextual Exploration of

Justice as Evenhandedness, Oxford University Press, Oxford.

Castells, M. 1996, The Rise of the Network Society, Blackwell Publishing, London. 
Davis, A. Y. 1996, 'Gender, Class, and Multiculturalism: Rethinking 'Race’ Politics,' in Mapping Multiculturalism, eds A. F. Gordon \& C. Newfield, University of Minnesota Press, Minneapolis, 40-48.

Day, R. J. F. 2000, Multiculturalism and the History of Canadian Diversity, University of Toronto Press, Toronto.

Dworkin, R. 1996, Freedom's Law, Harvard University Press, Cambridge, MA.

Edwards, B. H. 2003, The Practice of Diaspora: Literature, Translation, and the Rise of Black Internationalism, Harvard University Press, Cambridge, Mass.

Fish, S. 1997, 'Boutique Multiculturalism, or Why Liberals are Incapable of Thinking about Hate Speech,' Critical Inquiry, vol. 23, no. 2, 378-395.

Fitzmaurice, D. 1993, 'Autonomy as a Good: Liberalism, Autonomy and Toleration,' Journal of Political Philosophy, vol. 1, no. 1, 1-16.

Fraser, N. 1998, 'From Redistribution to Recognition? Dilemmas of Justice in a "PostSocialist' Age”, in Theorizing Multiculturalism: A Guide to the Current Debate, ed. C. Willett, Blackwell Publishing, Oxford, 19-49.

Fraser, N. \& Honneth, A. 2003, Redistribution or Recognition? A Political-Philosophical Exchange, Verso, London.

García Canclini, N. 2001, Consumers and Citizens: Globalization and Multicultural Conflicts, trans. by G. Yúdice, University of Minnesota Press, Minneapolis.

Giroux, H. A. 1996, Fugitive Cultures: Race, Violence, and Youth, Routledge, New York and London.

Gopinath, G. 2003, 'Nostalgia, Desire, Diaspora: South Asian Sexualities in Motion,' in Theorizing Diaspora: A Reader, eds J. Evans Braziel and A. Mannur, Blackwell Publishing, Oxford, 261-282.

Gordon, A. F. \& Newfield, C. (eds). 1996, Mapping Multiculturalism, University of Minnesota Press, Minneapolis, 40-48.

Gunew, S. 1999, 'The Melting Pot of Assimilation,' in Transnational Asia Pacific, eds S. G.-L. Lim, L. E. Smith \& W. Dissanayake, University of Illinois Press, Urbana and Chicago, 145-158.

Gutmann, A. 1998, Freedom of Association, Princeton University Press, Princeton.

Hall, S. 2000, 'Conclusion: the Multi-cultural Question,' in Un/settled Multiculturalisms, ed B. Hesse, Zed Books, London, 209-241.

Habermas, J. 1994, 'Struggles for Recognition in the Democratic Constitutional State,' in Multiculturalism: Examining the Politics of Recognition, ed. A. Gutmann, Princeton University Press, Princeton, 107-148.

Hesse, B. (ed.) 2000, Un/settled Multiculturalisms: Diasporas, Entanglements, 'Transruptions,' Zed Books, London.

Horrocks, R. \& Perry, N. (eds.) 2003, Television in New Zealand: Programming the Nation, Oxford University Press, Melbourne.

Hughes, R. 1993, Culture of Complaint: The Fraying of America, Oxford University Press, New York.

Kamboureli, S. 2000, Scandalous Bodies. Diasporic Literature in English Canada, Oxford University Press, Don Mills, Ont.

Kothari, S., Pearson, S. \& and Zuberi, N. 2003, 'Television and Multiculturalism in Aoteroa New Zealand,' in Television in New Zealand: Programming the Nation, eds R. Horrock \& N. Perry, Oxford University Press, Melbourne, 135-51. 
Kukathas, C. 1997, 'Cultural Toleration,’ Ethnicity and Group Rights: NOMOS XXXIX, eds. I. Shapiro and W. Kymlicka, New York University Press, New York, 69-104.

Kymlicka, W. 2001, Politics in the Vernacular: Nationalism, Multiculturalism, and Citizenship, Oxford University Press, Oxford.

1995, Multicultural Citizenship: A Liberal Theory of Minority Rights, Oxford University Press, Oxford.

Laclau, E. 2003, 'Universalism, Particularism and the Question of Identity,' in Identities: Race, Class, Gender, and Nationality, eds. L. M. Alcoff and E. Mendieta, Blackwell Publishing, Oxford, 360-368.

Levy, A. 2004, Small Island, Review, London.

Levy, J. T. 2000, The Multiculturalism of Fear, Oxford University Press, Oxford.

Lim, S. G.-L., Smith, L. E. \& Dissanayake, W. (eds.) 1999, Transnational Asia Pacific, University of Illinois Press, Urbana and Chicago.

Macedo, S. 2000, Diversity and Distrust: Civic Education in a Multicultural Democracy, Harvard University Press, Cambridge, Mass.

Marx, K. 1967 [1867], Capital, vol. 1: A Critique of Political Economy, International Publishers, New York.

Miller, D. 1999, Principles of Social Justice, Harvard University Press, Cambridge, Mass.

Mohanty, S. P. 1997, Literary Theory and the Claims of History, Cornell University Press, Ithaca, New York.

Morrison, T. 1996, 'Unspeakable Things Unspoken: The Afro-American Presence in American Literature,' Criticism and the Color Line: Desegregating American Literary Studies, ed. H. B. Wonham, Rutgers University Press, New Brunswick, NJ, 16-29.

Okin, S. M. 1999, Is Multiculturalism Bad for Women?, Princeton University Press, Princeton.

Olson, G. A. \& Worsham, L. (eds.) 1999, Race, Rhetoric and the Postcolonial, State University of New York Press, Albany.

Parekh, B. 2000a, The Future of Multi-Ethnic Britain: The Parekh Report, Profile Books, London.

2000b, Rethinking Multiculturalism: Cultural Diversity and Political Theory, Palgrave, London.

Pease, D. 1997, 'Regulating Multi-Adhoccerists, Fish('s) Rules,' Critical Inquiry, vol. 23, No. 2, 396-418.

Povinelli, E. A. 1998, 'The State of Shame: Australian Multiculturalism and the Crisis of Indigenous Citizenship,' Critical Inquiry, vol. 24, no. 2, 575-610.

Radhakrishnan, R. 2003. Theory in an Uneven World, Blackwell Publishing, Oxford.

Rawls, J. 1971, A Theory of Justice, Harvard University Press, Cambridge, Mass. 1996, Political Liberalism, Columbia University Press, New York. 1999, 'The Idea of Public Reason Revisited' in The Law of Peoples, Harvard University Press, Cambridge, MA.

Shachar, A. 2001, Multicultural Jurisdictions: Cultural Differences and Women's Rights, Cambridge University Press, Cambridge.

Shapiro, I \& Kymlicka, W. (eds.) 1997, Ethnicity and Group Rights: NOMOS XXXIX, New York University Press, New York. 
Taylor, C. 1994, Multiculturalism: Examining the Politics of Recognition, ed. A. Gutmann, Princeton University Press, Princeton.

Torres, R. D., Mirón, L. F., \& Inda, J. X. 1999, Race, Identity, and Citizenship: A Reader, Blackwell Publishing, Oxford.

Walzer, M. 1997, 'Response to Kukathas,' Ethnicity and Group Rights: NOMOS XXXIX, eds. I. Shapiro and W. Kymlicka, New York University Press, New York, 105-111.

Worsham, L. and Olson, G. A. 1999, 'Hegemony and the Future of Democracy: Ernesto Laclau's Political Philosophy,' Race, Rhetoric and the Postcolonial, eds. G. A. Olson and L. Worsham, State University of New York Press, Albany, 129-162.

Young, I. M. 2000, Inclusion and Democracy, Oxford University Press, Oxford.

Yuval-Davis, N. 1999, 'Ethnicity, Gender relations and Multiculturalism,' Race, Identity, and Citizenship: A Reader, eds R. D. Torres, L. F. Mirón and J. X. Inda, Blackwell Publishing, Oxford, 112-125.

Willett, C. (ed.) 1998, Theorizing Multiculturalism: A Guide to the Current Debate, Blackwell Publishing, Oxford.

Wonham, H. B. 1996, Criticism and the Color Line: Desegregating American Literary Studies, Rutgers University Press, New Brunswick, NJ.

Žižek, S. 1997, 'Multiculturalism, Or, the Cultural Logic of Multinational Capitalism,' New Left Review, no. 225, 28-51. 